\begin{tabular}{|c|c|c|}
\hline Beitr. Ent. & Keltern & ISSN 0005-805X \\
\hline $\mathbf{5 7}(2007) 1$ & S. $177-209$ & 30.06 .2007 \\
\hline
\end{tabular}

\title{
On the Aleocharini of Turkey, with notes on some species from adjacent regions
}

\section{(Coleoptera: Staphylinidae, Aleocharinae)}

With 102 figures and 1 table

VOLKer AsSING

\section{Summary}

Types and additional material of Aleocharini from Turkey and adjacent regions are revised. 6 species are (re-)described and illustrated: Megalogastria alata sp. n. (Bitlis, Erzurum), Aleochara caloderoides sp. n. (Mersin), A. (Ceranota) membranosa sp. n. (Antalya), A. (C.) bodemeyeri Bernhauer, 1914, A. (C.) bituberculata Bernhauer, 1900, and $A$. (C.) erythroptera Gravenhorst, 1806. External and sexual characters of $A$. (C.) caucasica Eppelsheim, 1889, A. (Rheochara) leptocera Eppelsheim, 1889, and A. (R.) spalacis SCHEERPELTZ, 1969 are figured. The following synonymy is proposed: Aleochara moesta GraVenhorst, 1802 = A. ebneri Scheerpeltz, 1929, syn. n. A lectotype is designated for A. spalacis Scheerpeltz. Additional records of Aleocharini from Turkey are reported, among them 7 first records. A checklist of the Aleocharini known from Turkish territory is compiled.

\section{Keywords}

Coleoptera, Staphylinidae, Aleocharinae, Aleocharini, Aleochara, Megalogastria, Pseudocalea, Tinotus, Palaearctic region, Turkey, taxonomy, new species, new records, distribution, checklist

\section{Zusammenfassung}

Typen und weiteres Material von Arten der Tribus Aleocharini aus der Türkei und angrenzenden Gebieten werden revidiert. 6 Arten werden beschrieben bzw. redeskribiert und abgebildet: Megalogastria alata sp. n. (Bitlis, Erzurum), Aleochara caloderoides sp. n. (Mersin), A. (Ceranota) membranosa sp. n. (Antalya), A. (C.) bodemeyeri Bernhauer, 1914, A. (C.) bituberculata Bernhauer, 1900 und $A$. (C.) erythroptera Gravenhorst, 1806. Äußere Merkmale sowie Geschlechtsmerkmale von $A$. (C.) caucasica Eppelsheim, 1889, A. (Rheochara) leptocera Eppelsheim, 1889 und $A$. (R.) spalacis Scheerpeltz, 1969 werden abgebildet. Aleochara ebneri Scheerpeltz, 1929, syn. n., wird mit A. moesta Gravenhorst, 1802 synonymisiert. Für A. spalacis Scheerpeltz wird ein Lectotypus designiert. Weitere Nachweise, darunter 7 Erstnachweise, von Aleocharini aus der Türkei werden gemeldet. Für die derzeit aus der Türkei bekannten Arten der Aleocharini wird eine Checklist erstellt.

\section{Neue Arten}

Megalogastria alata sp. n., Aleochara caloderoides sp. n., A. (Ceranota) membranosa sp. n. 


\section{Introduction}

In a recent catalogue (SMETANA, 2004), 32 species of Aleocharini are listed for Turkey, 2 species of Pseudocalea Luze and 30 species of Aleochara Gravenhorst. In the meantime, one additional species of Pseudocalea and eight species of Aleochara have been reported or described from Turkish territory (Assing 2006b, 2007).

The present paper is based on a revision of type material of several species, as well as on an examination of additional material, most of which was collected during several recent field trips or found in the Schubert collection at the Naturhistorisches Museum Wien. Several undescribed species were discovered; some of them, however, are represented only by females and consequently not described. The identities of several additional species are still uncertain and will have to be clarified in future studies.

Including the three new species described here, a total of 48 species of Aleocharini are now known from Turkey. A comparison with the diversity from Central Europe, which should be expected to be lower, but from where as many as 55 species in 3 genera have been recorded (AssIng \& SchüLKE, in press), shows that the currently known inventory of Turkey is still rather incomplete. Numerous widespread and common species have been reported from adjacent countries, but not from Turkish territory. This is exemplified in the fact that, up to today, not a single intertidal species (species of the subgenera Polystomota CASEY and Emplenota CASEY) is known from the coasts of Turkey.

\section{Material, methods, and abbreviations}

The material examined is deposited in the following collections:

$\begin{array}{ll}\text { FMNH } & \text { Field Museum of Natural History, Chicago (J. Boone) } \\ \text { HUA } & \text { Hacettepe University Beytepe, Ankara (S. Özdemir) } \\ \text { MHNG } & \text { Museum d'histoire naturelle Genève (G. Cuccodoro) } \\ \text { NMW } & \text { Naturhistorisches Museum Wien (H. Schillhammer) } \\ \text { cAss } & \text { author's private collection } \\ \text { cSch } & \text { private collection M. Schülke, Berlin } \\ \text { cWun } & \text { private collection P. Wunderle, Mönchengladbach }\end{array}$

The morphological studies and drawings were carried out using a Stemi SV 11 microscope (Zeiss Germany) and a Jenalab compound microscope (Carl Zeiss Jena) with a drawing tube. For the photographs a digital camera (Nikon Coolpix 995) was used.

The measurements are given in $\mathrm{mm}$ and abbreviated as follows:

AL: length of antenna; AW: maximal width of abdomen; EL: length of elytra along suture, from apex of scutellum to posterior margin; EW: combined width of elytra; HL: head length from anterior margin of clypeus to neck; HW: maximal head width; ML: length of median lobe of aedeagus from base to apex of ventral process; PL: length of pronotum along midline; PW: maximal width of pronotum; TaL: length of metatarsus; TiL: length of metatibia; TL: body length from mandibles to apex of abdomen. 


\section{Species descriptions and additional records}

\section{Pseudocalea angulata (EPPELSHEIM, 1880)}

Material examined: Mersin: 1 ex., ca. $30 \mathrm{~km}$ NNW Tarsus, $37^{\circ} 10 \mathrm{~N}, 34^{\circ} 46 \mathrm{E}, 580 \mathrm{~m}$, fallow with deciduous trees, 26.XII.2000, leg. Assing (cAss); 2 exs., 30 km NW Erdemli, S Yağda, 36ํ4N, 3403E, $1310 \mathrm{~m}$, Abies forest, 29.XII.2000, leg. Assing, Wunderle (cAss, cWun); 3 exs., a. $25 \mathrm{~km} \mathrm{NW}$ Erdemli, 36 $42 \mathrm{~N}, 34^{\circ} 10 \mathrm{E}$, $1085 \mathrm{~m}$, litter of deciduous trees, 29.XII.2000, leg. Assing (cAss).

The species was previously known from several Balkans countries and from Istanbul (Assing, 2000; Bernhauer, 1902; Smetana, 2004). It is here reported from Anatolia for the first time.

\section{Tinotus morion (GravenHORST, 1802)}

Material examined: Mersin: 1 ex., Çamlıyayla, VI.1962, leg. Schubert (cAss).

Although widespread in the Palaearctic region, T. morion was previously unknown from Turkish territory (SMETANA, 2004).

\section{Megalogastria alata sp. n. (Figs 1-14)}

\section{Type material:}

Holotype $\sigma^{\star}$ : Bitlis, $20 \mathrm{~km}$ See Bitlis, Dogruyol, $1400 \mathrm{mH}$, Bachlauf, mit Bäumen 80 \%, Leg. Schulz, 15.06.93, Türkei / Holotypus ơ Megalogastria alata sp. n. det. V. Assing 2006 (cAss). Paratypes: $2 \sigma^{\star} o^{\star}$ : same data as holotype (cAss); $10^{\star}$ : Paladöken Dag, 2300 m, Erzurum / 21.6.73, leg. F. Schubert (NMW).

\section{Description:}

Measurements (in mm) and ratios (range; n=3): AL: 0.98-1.10; HL: 0.51-0.53; HW: 0.530.54; PW: 0.85-0.92; PL: 0.59-0.62; EL: 0.48-0.56; EW: 1.07-1.16; AW: 1.00-1.06; TiL: 0.69-0.74; TaL: 0.57-0.63; ML: 0.63-0.68; TL: 4.2-4.9; HL/HW: 0.94-0.97; PW/HW: 1.581.69; PW/PL: 1.43-1.49; EL/PL: 0.80-0.90; EW/PW: 1.26-1.32; AW/EW: 0.91-0.93; TiL/ TaL: $1.17-1.21$.

Coloration distinctive: head black; pronotum bright reddish to castaneous; elytra reddish yellow; abdomen black, with reddish apex (posterior half of segment VIII and following segments); legs and antennae yellowish brown, with antennomeres I-III yellowish; apex of antennomere XI whitish; maxillary palpi yellowish.

Habitus as in Fig. 1. Head of suborbicular shape, approximately as wide as long (see ratio HL/ HW), posterior angles absent (Fig. 2); postgenal carinae distinct; puncturation very fine and moderately sparse; pubescence moderately long, pale, and suberect; interstices without microsculpture. Eyes large (Fig. 3), much longer than postocular region in dorsal view. Antennae short and fine in relation to body (Fig. 1); antennomeres I-III of subequal length; IV subquadrate to weakly transverse; V-X moderately transverse, less than 1.5 times as wide as long, and weakly increasing in width; XI oblong, with membranous apex (Fig. 4). Maxillary palpus stout, apical palpomere of conical shape and with weakly constricted pseudosegment (Fig. 6); labium with short and stout, 3 -jointed labial palpus without apical pseudosegment; ligula short, bifid, and with pair of apical setae (Fig. 5). 


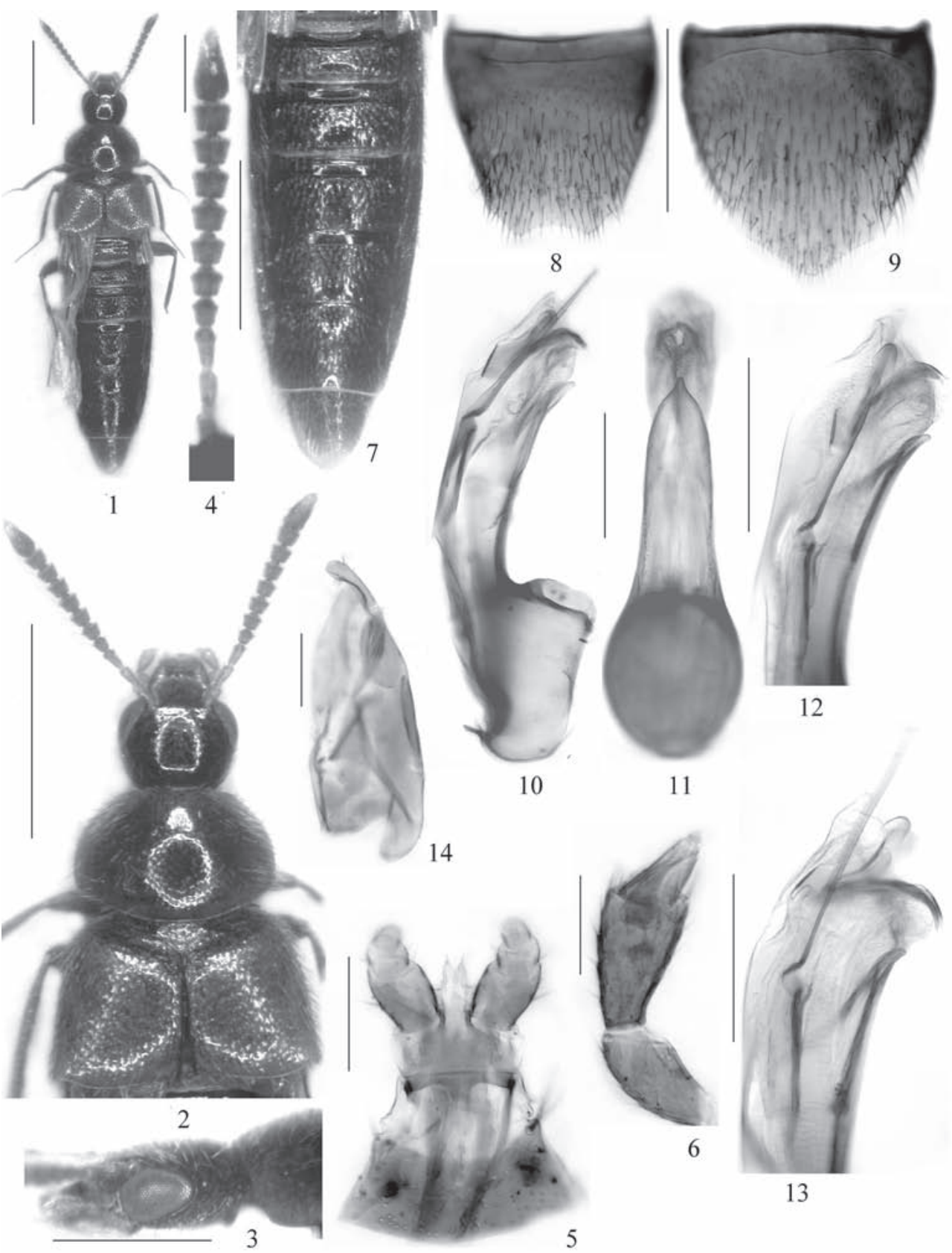

Figs 1-14: Megalogastria alata: habitus (1); forebody (2); head in lateral view (3); antenna (4); labium (5); maxillary palpus (6); abdomen (7); male tergite VIII (8); male sternite VIII (9); median lobe of aedeagus in lateral and in ventral view (10-11); apical part of median lobe in lateral view (12-13); paramere (14). Scale bars: 1-2, 7: $1.0 \mathrm{~mm}$; 3, 8-9: 0.5 mm; 4, 10-14: $0.2 \mathrm{~mm}$; 5-6: $0.1 \mathrm{~mm}$. 
Pronotum strongly transverse and large in relation to head (see ratios PW/PL and PW/HW); maximal width a short distance behind middle; posterior angles weakly marked, almost completely rounded (Fig. 2); pronotal hypomera not visible in lateral view; puncturation similar to that of head; pubescence directed caudad along midline and predominantly diagonally latero-caudad in lateral areas; microsculpture absent.

Elytra approximately 1.3 times as wide as and at suture somewhat shorter than pronotum (see ratios EW/PW and EL/PL), slightly widened posteriorly; posterior margin weakly sinuate near posterior angles; puncturation coarse and well-defined, more distinct than that of head and pronotum; microsculpture absent (Fig. 2). Hind wings fully developed. Legs slender; metatarsus almost as long as metatibia (see ratio $\mathrm{TiL} / \mathrm{TaL}$ ); metatarsomere I conspicuously long, approximately as long as the combined length of II-IV or even longer.

Abdomen widest at segments III-IV, gradually tapering caudad; tergites III-V without distinct anterior impressions, only with anterior ridge; tergites III-VI and anterior $1 / 3$ of tergite VII with conspicuously coarse and rather dense puncturation; posterior $2 / 3$ of tergite VII with finer and sparse puncturation; microsculpture absent; posterior margin of tergite VII with distinct palisade fringe (Fig. 7).

$\sigma^{*}$ : posterior margin of tergite VIII concave in the middle (Fig. 8); sternite VIII posteriorly pointed (Fig. 9); median lobe of aedeagus shaped as in Figs 10-13; paramere as in Fig. 14.

i: unknown.

Etymology: The name (Lat., adj.) alludes to the fact that, in contrast to $M$. cingulata (EPPELsheim), the hind wings are fully developed.

\section{Comparative notes:}

The morphologically remarkable genus Megalogastria, whose phylogenetic affiliations are still somewhat uncertain, previously included only the type species $M$. cingulata from western and northwestern Turkey (Assing, 2007). From this species, M. alata is distinguished by numerous characters, i. e. the distinctly larger size, the larger eyes, the more slender antennae (antennomeres VI-X in $M$. cingulata more than 1.5 times as wide as long), the stouter maxillary palpus with a less slender apical palpomere, the larger and more transverse pronotum, the longer and larger elytra, the fully developed hind wings, the much longer and more slender tarsi, the denser and coarser puncturation of the abdomen, the dark coloration of the anterior abdominal segments (in $M$. cingulata reddish), the posteriorly concave male tergite VIII (in $M$. cingulata convex), as well as by the morphology of the median lobe of the aedeagus. For illustrations of $M$. cingulata see figures 125-135 in Assing (2007).

\section{Distribution and bionomics:}

The species was found in two localities in Bitlis (20 km ESE Bitlis) and Erzurum provinces, eastern Anatolia, at altitudes of 1400 and $2300 \mathrm{~m}$. The specimens from Bitlis were collected near a stream, possibly associated with ants.

\section{Aleochara caloderoides sp. n. (Figs 15-26, 84-86)}

\section{Type material:}

Holotype $o^{\star}$ : TR-Südküste, Str. Anamur, 30 km i.R. Ermenek, 800 m, 17.5.2000, Meybohm/ Brachat / Holotypus ơ Aleochara caloderoides sp. n. det. V. Assing 2006 (cAss). Paratypes: 1 ㅇ : TR Mersin (33), road to Arslanköy, 5 km SE Aladag, 700 m / 365 $54^{\prime} 45 \mathrm{~N}, 34^{\circ} 31^{\prime} 44 \mathrm{E}, 10.5 .2004$, 


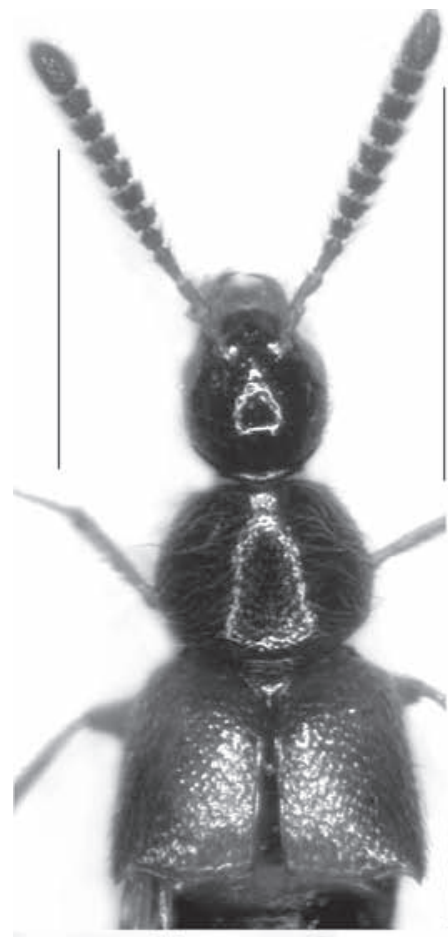

15

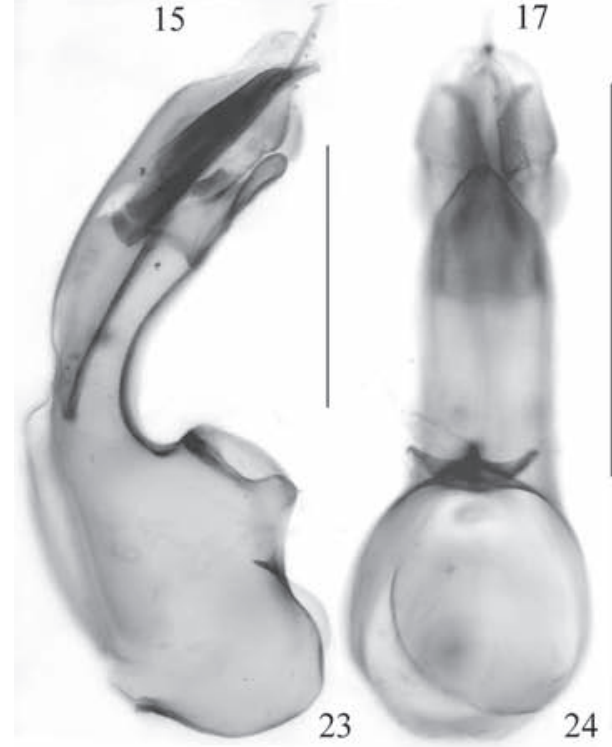

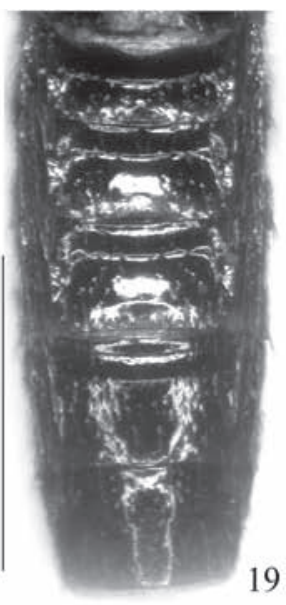
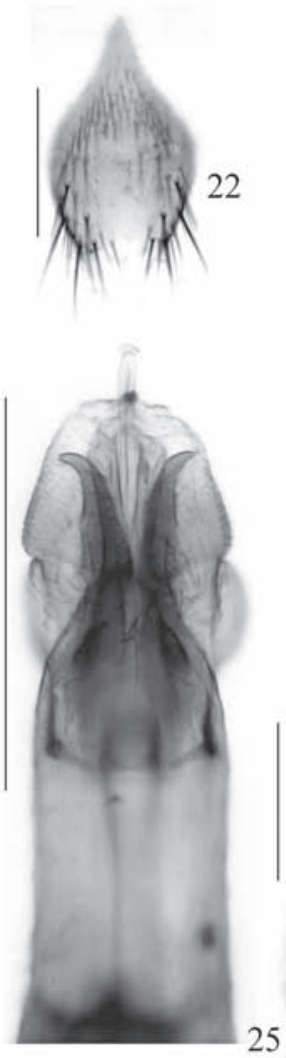
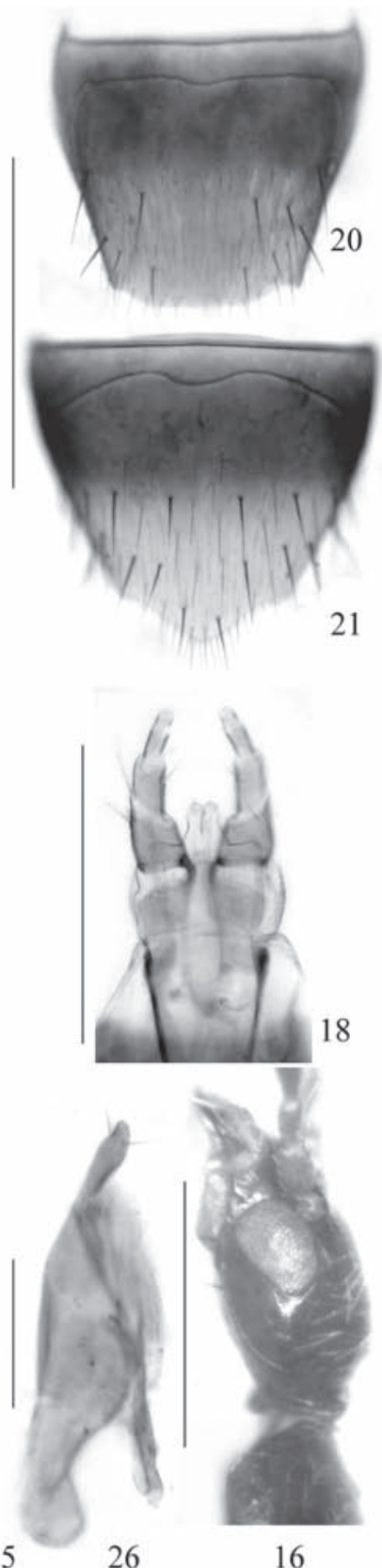

16

Figs 15-26: Aleochara caloderoides: forebody (15); head in lateral view (16); antenna (17); labium (18); abdomen (19); male tergite VIII (20); male sternite VIII (21); tergite X (22); median lobe of aedeagus in lateral and in ventral view (23-24); apical internal structures of median lobe in ventral view (25); paramere (26). Scale bars: 15, 19: $1.0 \mathrm{~mm}$; 16-17, 20-21: $0.5 \mathrm{~mm}$; 18, 22-26: $0.2 \mathrm{~mm}$. 
leg. Brachat \& Meybohm (cAss); $10^{\star}:$ TR - Mersin [33], road to Arslanköy, $5 \mathrm{~km}$ SE Aladag, $700 \mathrm{~m}, 36^{\circ} 54^{\prime} 45 \mathrm{~N}, 34^{\circ} 31^{\prime} 44 \mathrm{E}, 2$.V.2004, C. Besuchet (cAss).

\section{Description:}

Measurements (in mm) and ratios (range; $n=3$ ): AL: 1.10-1.25; HL: 0.51-0.55; HW: 0.47-0.53; PW: 0.68-0.80; PL: 0.56-0.66; EL: 0.54-0.59; EW: 0.91-1.03; AW: 0.79-0.89; TiL: 0.62-0.66; TaL: 0.47-0.50; ML: 0.45-0.51; TL: 4.0-4.7; HL/HW: 1.03-1.10; PW/HW: 1.45-1.55; PW/PL: 1.16-1.23; EL/PL: 0.89-0.97; EW/PW: 1.26-1.33; AW/EW: 0.85-0.88; TiL/TaL: 1.32-1.42.

Coloration: body bicoloured: head black; pronotum blackish brown; elytra dark yellowish, with the scutellar and the postero-lateral area more or less distinctly infuscate; abdomen black, with the narrow posterior margins of segments III-VI and the posterior 1/3-1/2 of segments VII-VIII paler; legs and palpi yellowish; antenna bicoloured, with antennomeres I-III yellowish and IV-XI dark brown.

Head oblong and of oval shape, posterior angles obsolete (Fig. 15); puncturation rather sparse and well-defined; interstices distinctly wider than diameter of punctures; pubescence long, greyish, and suberect; microsculpture almost absent (very shallow traces visible in places). Eyes large (Fig. 16), but weakly bulging, slightly longer than postocular region in dorsal view. Antennae of distinctive morphology: antennomeres I-III distinctly oblong and of subequal length; IV weakly transverse and distinctly smaller than V; V-X moderately transverse and of subequal width, approximately 1.5 times as wide as long; XI approximately as long as the combined length of IX-X (Fig. 17). Labium as in Fig. 18.

Pronotum distinctly transverse and moderately large in relation to head (see ratios PW/PL and PW/HW); maximal width approximately in the middle; posterior angles weakly marked, almost obsolete (Fig. 15); pronotal hypomera very narrowly visible in lateral view; puncturation fine, distinctly finer than that of head, and moderately dense; interstices wider than diameter of punctures; pubescence directed caudad along midline and almost transversely laterad in lateral areas; microsculpture absent.

Elytra approximately 1.3 times as wide and at suture about as long as pronotum; posterior margin moderately sinuate near posterior angles; puncturation distinctly coarser than that of head and pronotum; microsculpture absent (Fig. 15). Hind wings fully developed. Mesosternum without median carina, at most with very short rudiment anteriorly. Metatarsomere I longer than the combined length of II-III, but shorter than the combined length of II-IV.

Abdomen widest at base, gradually tapering posteriad; tergites III-V with moderately deep and almost impunctate anterior impressions, puncturation fine and sparse; tergites III-VI without microsculpture and very glossy; tergite VII with shallow microsculpture; posterior margin of tergite VII with distinct palisade fringe (Fig. 19).

$\sigma^{\text {t }}$ : posterior margin of tergite VIII truncate in the middle (Fig. 20); sternite VIII posteriorly distinctly pointed (Fig. 21); tergite $\mathrm{X}$ as in Fig. 22; median lobe of aedeagus shaped as in Figs 23-25, with distinctive internal structures; paramere as in Fig. 26.

ㅇ: posterior margin of tergite VIII distinctly convex (Fig. 84); posterior margin of sternite VIII broadly and moderately convex (Fig. 85); spermatheca with capsule of distinctive shape and with long and almost straight duct (Fig. 86).

Etymology: The name (Lat., adj.) refers to the morphology of the antennae, which somewhat resembles that of species of Calodera ManNerheim. 
Comparative notes and subgeneric affiliations:

Based on the absence of the median carina on the mesosternum, the species would have to be attributed to the subgenera Aleochara, Euryodma, or Heterochara. However, there are no derived characters linking it to any of the species currently attributed to these taxa. Among the Aleochara species of the Western Palaearctic region, $A$. caloderoides holds a somewhat isolated position with a distinctive character combination: small size, antennae resembling those of Calodera, relatively slender pronotum (similar in shape to that of $A$. inconspicua), mesosternum without median carina, abdomen in shape, shine, and puncturation resembling that of some species of Ocalea, and an aedeagus of similar morphology as that of some species of Ceranota. In view of the uncertain phylogenetic affiliations of this species, it is not attributed to any of the described subgenera.

\section{Distribution and bionomics:}

The type locality is situated in Mersin province, southern Anatolia. Apart from the altitude $(800 \mathrm{~m})$, bionomic data are not available.

\section{Aleochara (Aleochara) curtula (GoEZE, 1777)}

Material examined: Ardahan: 1 ex., Ardahan, 1600 m, 1.-2.VI.1969, leg. Schubert (NMW).

This cosmopolite had been recorded from Turkey before (SMETAna, 2004).

\section{Aleochara (Aleochara) laticornis KRAATZ, 1856}

Material examined: Antalya: 15 exs., Beydağları, Saklikent, 1650-1900 m, 17.VI.1994, leg. Pütz (cAss). Konya: 1 ex., Beyşehir, Çamlık env., 29.IV.-1.V.2001, leg. Lohaj (cAss); 2 exs., Aksehir env., Sultan Dağları, 4.\&19.V.1960, leg. Petrowitz \& Ressl (NMW). Mersin: 1 ex., Erdemli, 7.-10.V.1965, leg. Schubert (NMW). Antakya: 2 exs., Iskenderun, 9.IV.1960, leg. Petrowitz \& Ressl (NMW, cAss).

The species is widespread in the Western Palaearctic region and had been recorded from Turkey before (SMETANa, 2004).

\section{Aleochara (Baryodma) intricata MANNERHEIM, 1830}

Material examined: Istanbul: 3 exs., "Belgrader Wald”, 1.-7.VII.1954, leg. Schubert (NMW, cAss). Konya: 1 ex., Akşehir env., 15.IV.1960, leg. Petrowitz \& Ressl (NMW). Ankara: 1 ex., Beytepe, 9.X.2006, leg. Özdemir (HUA). Mersin: 1 ex., Çamlıyayla, 1200 m, V.1967, leg. Schubert (cAss). Osmaniye: 1 ex., Osmaniye, 1200 m, VI.1967, leg. Schubert (cAss); 1 ex., E Osmaniye, 1200-1700 m, leg. Schubert (NMW). Antakya: 2 exs., Yayladağı, 450 m, 17.V.1973, leg. Schubert (NMW). Urfa: 1 ex., Halfeti, 27.V.1987, leg. Schönmann \& Schillhammer (NMW). Bitlis: 1 ex., Bitlis, 1800 m, 28.V.1969, leg. Schubert (NMW); 2 exs., S Tatvan, 1700-2000 m, 212.V.-18.VI.1973, leg. Schubert (NMW); 1 ex., S Tatvan, 1700-2000 m, 1971, leg. Schubert (NMW); 1 ex., Tatvan, 1900 m, 20.V.1969, leg. Schubert (NMW). Van: 1 ex., E Van lake, 1800-2200 m, VI.1968, leg. Schubert (NMW).

For additional records and comments see Assing (2007).

\section{The Turkish species of Ceranota}

The subgenus Ceranota Stephens, 1839 of the genus Aleochara currently includes 26 valid species, all of them confined to the Western Palaearctic region (Assing 2006a, Smetana 2004). Seven of these species have become known from Turkish territory, one of them with unspecified type locality. There is little doubt that the Ceranota fauna of Turkey is much more diverse than 
currently known, not only because the material examined in the course of the present study included several undescribed species. The total number of specimens that have become available from Turkey so far amounts to some 30 beetles (including types and literature records). The real habitats of Ceranota species are cryptic and largely unknown, so that records by hand-collecting are usually accidental. Moreover, there is some evidence that at least some, if not the majority of species are active especially during the cold season (autumn to early spring), when collecting activity is generally much lower than in late spring and summer. Adult beetles have repeatedly been encountered on or near snow (HoRion, 1967). For a study and illustrations of the life histories of three Central European species see Assing (1994).

Species identification is complicated by the fact that not only size-related parameters, but also other characters such as the coloration, the puncturation, and the modifications of the tergites of the male abdomen may be subject to considerable intraspecific variation and interspecific overlap. Moreover, the spermatheca and the shape and chaetotaxy of the paramere are rather uniform and consequently of little taxonomic use. The most reliable diagnostic character is the morphology of the median lobe of the aedeagus. Additional useful characters are the morphology of the clypeus and the antennae, the microsculpture of the forebody, the length of elytra and hind wings, the length of the legs, the puncturation of the abdomen, the modifications of the male abdominal tergites (including the shape and chaetotaxy of tergite VIII), as well as the modifications of the

male abdominal sternites IV and V.

Aleochara (Ceranota) membranosa sp. n. (Figs 27-40)

\section{Type material:}

Holotype $0^{\star}:$ TR [2] - Antalya, $40 \mathrm{~km}$ E Alanya, 1530-1600 m, pine litter \& grass sifted, $36^{\circ} 29 \mathrm{~N}, 32^{\circ} 23 \mathrm{E}, 23 . X I I .2006$, V. Assing / Holotypus o Aleochara membranosa sp. n. det. V. Assing 2006 (cAss). Paratypes: $10^{\star}$ : TR - Antalya, No. 9, SW Akyazı, NE Belpinar pass, grassland, $870 \mathrm{~m}, 36^{\circ} 22^{\prime} 24 \mathrm{~N}, 29^{\circ} 29^{\prime} 59 \mathrm{E}, 26 . I I I .2002$, V. Assing (cAss); $1 \mathrm{o}^{*}: \mathrm{TR}$ - Antalya, 0-50 m, Umg. Manavgat, 21, 03.I.1991, Assing (cAss).

\section{Description:}

Measurements (in mm) and ratios (holotype, paratype 1, paratype 2): AL: 2.10, 1.62, 1.53; HL: 1.01, 0.80, 0.72; HW: 1.04, 0.73, 0.69; PW: 1.51, 1.09, 1.01; PL: 1.09, 0.77, 0.74; EL: 0.85, 0.60, 0.53; EW: 1.72, 1.21, 1.12; AW: 1.65, 1.21, 1.09; TiL: 1.28, 0.92, 0.85; TaL: 1.01, 0.72, 0.66; ML: 0.74, 0.68, 0.66; TL: 8.2, 5.7, 5.5; HL/HW: 0.97, 1.09, 1.04; PW/HW: 1.45, 1.48, 1.46; PW/PL: 1.39, 1.41, 1.37; EL/PL: 0.78, 0.78, 0.71; EW/PW: 1.14, 1.11, 1.10; AW/EW: 0.96, 1.00, 0.97; TiL/TaL: 1.27, 1.27, 1.27.

Coloration: head blackish; pronotum reddish brown to castaneous with reddish margins; elytra reddish; abdomen dark brown, with the broad posterior and lateral tergal margins and the apex (segments VIII and following) reddish yellow; legs reddish; antennae with antennomeres I-III reddish and IV-XI infuscate.

Habitus as in Fig. 27. Head of distinctive morphology: weakly oblong (see ratio HL/HW); clypeus fully membranous, its anterior margin deeply triangularly incised (Fig. 29); puncturation very fine to moderately fine, shallow, and sparse, sometimes barely noticeable in the distinct microreticulation (Fig. 28); eyes moderately large and prominent, approximately as long as postocular region in dorsal view; sides of head not vertical, but smoothly sloping downwards, both eyes almost fully visible simultaneously in dorsal view (Fig. 29). Antennae slender; antennomere 




Figs 27-40: Aleochara membranosa: habitus (27); forebody (28); head in antero-dorsal view (29); antenna (30); abdomen (31); male sternites IV-V in latero-ventral view (32); male tergite III (33); male tergites VIIVIII (34); male tergite VIII (35); male sternite VIII (36); median lobe of aedeagus in lateral and in ventral view (37-39); paramere (40). Scale bars: 27-28, 31-32: $1.0 \mathrm{~mm}$; 29-30, 33-40: $0.5 \mathrm{~mm}$. 
IV approximately as long as wide; preapical antennomeres weakly transverse, less than 1.5 times as wide as long (Figs 28,30). Maxillary palpus slender, palpomere III approximately 3.5-4 times as long as wide (Fig. 29).

Pronotum distinctly wider than head and strongly transverse (see ratios PW/HW and PW/PL), but not very large in relation to head; maximal width in or slightly behind middle; posterior angles weakly marked, almost completely rounded; puncturation slightly more distinct than that of head; surface with distinct microreticulation (Fig. 28).

Elytra not much wider and at suture distinctly shorter than pronotum (see ratios EW/PW and EL/PL); posterior margins weakly sinuate near posterior angles; suture more or less distinctly elevated (at least in $\sigma^{\top}$ ), in paratypes only in posterior half; puncturation moderately dense, welldefined, and somewhat granulose, much more distinct than that of head and pronotum; interstices with microreticulation similar to that of pronotum (Fig. 28). Hind wings of reduced length, barely reaching anterior margin of tergite $\mathrm{V}$ (with abdomen fully extended). Legs slender; metatarsomere I as long as the combined length of II-IV or nearly so.

Abdomen with segments III-VI subparallel; tergites III-V with shallow anterior impressions, anterior impression of tergite VI barely noticeable; puncturation of tergites III-VI very sparse, central parts of these tergites almost impunctate; tergite VII with sparse and moderately coarse puncturation, its posterior margin with narrow palisade fringe (Fig. 31); tergites III and VII-VIII modified at least in male.

$\sigma^{\star}$ : tergite III with subcircular or apically longitudinally keeled median tubercle of variable size and elevation near posterior margin (Fig. 33); tergite VII at posterior margin with weakly elevated transverse glossy bulge (Fig. 34), in holotype with coarsely rugose sculpture anterior to this bulge; sternites IV and V without distinct impressions, in anterior halves with transverse tomentose patches with dense long golden pubescence and distinct microsculpture (Fig. 32); posterior margin of tergite VIII concave (Fig. 35); posterior margin of sternite VIII pointed (Fig. 36); median lobe of aedeagus rather stout and with ventral process of distinctive shape, especially in lateral view (Figs 37-39); paramere as in Fig. 40.

i: unknown.

\section{Intraspecific variation:}

The holotype is considerably larger than the paratypes (see measurements) and has more pronounced secondary sexual characters.

Etymology: The name (Lat., adj.) alludes to the conspicuously membranous clypeus.

\section{Comparative notes:}

Aleochara membranosa is separated from its consubgeners especially by the primary and secondary male sexual characters, from most species also by the pronounced microreticulation of the head and pronotum, the position of the eyes (almost fully visible in dorsal view), the membranous clypeus, and by the reduced length of the hind wings. From other Ceranota species recorded from Turkey and adjacent regions it is additionally distinguished as follows:

from $A$. adusta Eppelsheim, 1890 (Caucasus region; type material examined) by a broader head and pronotum, shorter and reddish elytra, sparser and more distinctly granulose elytral puncturation, sparser puncturation of the abdomen, and longer tarsi;

from A. bituberculata Bernhauer, 1900 (Turkey) by more slender antennae, larger and more prominent eyes, by more coarsely punctate elytra, and by more sparsely punctate tergites III-VI; 
from $A$. bodemeyeri Bernhauer, 1914 (Turkey) by distinctly larger size, longer, more slender and darker antennae, a larger and more transverse pronotum, less dense puncturation of the elytra, and a sparser puncturation of the abdomen;

from A. caucasica Eppelsheim, 1889 (Caucasus region; holotype and additional specimen from coll. Bernhauer examined), which, too, has a microsculptured pronotum, by longer and more slender antennae, a differently shaped (less convex, more transverse) pronotum, shorter and uniformly coloured elytra (in $A$. caucasica with infuscate posterior angles), and by longer metatarsi; for comparison see Figs 87-96;

from A. erythroptera Gravenhorst, 1806 (West Palaearctic) [several specimens from Central Europe examined] by much finer and sparser puncturation of the head and pronotum, the less dark coloration of the pronotum (in A. erythroptera usually black), shorter and more sparsely punctate elytra, and a much more sparsely punctate abdomen;

from A. libanica Eppelsheim, 1889 (Lebanon, Syria; type material examined) by less slender head and pronotum, shorter and reddish elytra, sparser and more distinctly granulose elytral puncturation, sparser puncturation of the abdomen, and longer tarsi;

from A. lucidula Hochнuтh, 1860 (Caucasus region, Ukraine; specimens from coll. Bernhauer examined) by more slender antennae, a larger head (in relation to pronotum), a more transverse pronotum, much shorter elytra, and sparser puncturation of the abdomen;

from A. lurida Motschulsky, 1860 (Caucasus region, Turkey), which is characterised by a conspicuously shiny forebody, by the larger head (in relation to pronotum), and the darker pronotum (in $A$. lurida reddish);

from A. ocaleoides (Bernhauer, 1902) (Turkey; type material examined), which was originally placed in Amarochara Thomson, by darker coloration of the pronotum, longer and more slender antennae (in A. ocaleoides apically distinctly incrassate with strongly transverse preapical antennomeres), and shorter elytra;

from A. plicata Lokay, 1907 (Turkey: Adana), which is characterised by modifications of the male abdominal tergites III-V and VII-VIII, by a larger head (in relation to pronotum);

from A. ruficornis GravenHORST, 1802 (Europe; numerous specimens examined) by darker antennae, the sparser and finer puncturation of the head and pronotum, the smaller and more transverse pronotum, the shorter and more sparsely punctate elytra, and by the sparser puncturation of the abdomen;

from A. strasseri Bernhauer, 1901 (Balkans) (specimens from Bosnia-Herzegovina and Greece examined), with which it shares the membranous clypeus and the similar modifications of the male abdominal tergites III and VII, by much longer and more slender antennae, larger eyes (in A. strasseri distinctly shorter than postocular region in dorsal view), the distinctly microsculptured forebody (in $A$. strasseri shiny and without microsculpture), a pronotum with more convex lateral margins, distinctly longer tarsi, a longer metatarsomere I (in $A$. strasseri approximately as long as the combined length of II-III), sparser puncturation of the central areas of the abdominal tergites, and by the concave posterior margin of abdominal tergite VIII (in A. strasseri convex);

from A. subtumida (Hochнuth, 1840) (Caucasus region, Turkey; several specimens from Turkey and the Caucasus region examined) by the paler coloration of the pronotum (in A. subtumida black), the larger (in relation to pronotum) and less slender head; the much finer and sparser puncturation of the head and pronotum, the more transverse pronotum, the distinctly narrower and shorter elytra, the sparser and more well-defined elytral puncturation, the absence of a tubercle on the male elytra, and by the much sparser puncturation of the abdomen. 


\section{Distribution and bionomics:}

The species is known from three localities in Antalya province, southwestern Anatolia. The holotype was sifted from litter and grass beneath scattered old pine trees at an altitude of approximately $1600 \mathrm{~m}$ at the end of December, one paratype from litter of pine and shrubs at little above sea-level in the beginning of January, and the other paratype from grass near a road margin at an altitude of nearly $900 \mathrm{~m}$ at the end of March.

\section{Aleochara (Ceranota) bodemeyeri BERNHAUER, 1914 (Figs 41-45)}

Aleochara (Ceranota) bodemeyeri Bernhauer, 1914: 43.

\section{Type material examined:}

Syntype $:$ : Asia Minor, Goek-Dagh, v. Bodemeyer / libanica Epp. det. Bernhauer / Bodemeyeri Brnh. Typus / Chicago NHMus M.Bernhauer Coll. / Syntypus o Aleochara bodemeyeri Bernhauer rev. V. Assing 2006 (FMNH).

\section{Comments:}

The original description is based on two syntypes, both of which are probably females: „Geschlechtsauszeichnungen treten an den vorliegenden Stücken nicht hervor" (BernHauer, 1914). Only one of these syntypes was found in the Bernhauer collection at the FMNH; the depository of the second type specimen is unknown. Since there is a slight chance that the second syntype may eventually be found and turn out to be a small male without apparent secondary sexual characters, the above female is not designated as the lectotype.

Additional material examined: Turkey, Bolu: 1 ex., Abant Gölü, 20.V.1987, leg. Schönmann \& Schillhammer (NMW).
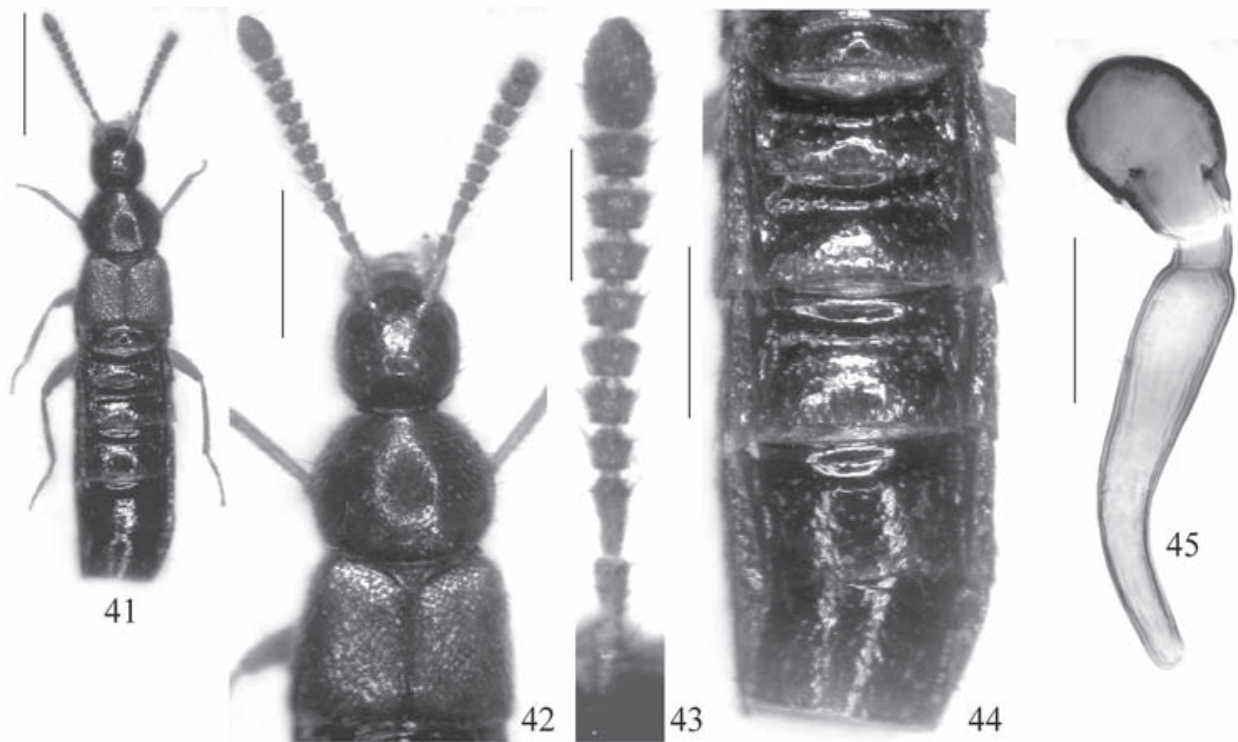

Figs 41-45: Aleochara bodemeyeri (syntype): habitus (41); forebody (42); antenna (43); abdomen (44); spermatheca (45). Scale bars: 41: $1.0 \mathrm{~mm}$; 42, 44: $0.5 \mathrm{~mm}$; 43: $0.2 \mathrm{~mm}$; 45: $0.1 \mathrm{~mm}$. 


\section{Redescription:}

Measurements (in mm) and ratios (syntype): AL: 1.10; HL: 0.50; HW: 0.45; PW: 0.66; PL: 0.54; EL: 0.45; EW: 0.79; AW: 0.79; TiL: 0.60; TaL: 0.47; TL: 3.9; HL/HW: 1.10; PW/HW: 1.47; PW/PL: 1.22; EL/PL: 0.83; EW/PW: 1.18; AW/EW: 1.00; TiL/TaL: 1.29.

Coloration: head and abdomen, except for the posterior margins of the segments and the apex, blackish; pronotum reddish brown; elytra reddish; legs dark yellowish; antennae reddish.

Habitus as in Fig. 41. Head oblong (see ratio HL/HW); clypeus unmodified; puncturation fine and sparse; interstices with shallow microsculpture. Eyes moderately large, slightly shorter than postocular region in dorsal view (Fig. 42). Antennae distinctly incrassate; preapical antennomeres more than 1.5 times as wide as long (Fig. 43).

Pronotum moderately large and moderately transverse (see ratios PW/HW and PW/PL), widest approximately in the middle; puncturation rather dense, but very shallow, fine, and rather ill-defined; interstices with very shallow microsculpture (Fig. 42).

Elytra distinctly wider and at suture shorter than pronotum (see ratios EW/PW and EL/PL); posterior margin near posterior angles sinuate; puncturation dense and somewhat granulose; microsculpture absent. Metatarsus rather short and stout (see measurements); metatarsomere I almost as long as the combined length of II-IV.

Abdomen with segments III-VI subparallel; tergites III-V with rather deep anterior impressions, anterior impression of tergite VI practically obsolete; puncturation distinct and moderately sparse, present also in anterior impressions of tergite III-V; posterior margin of tergite VII with palisade fringe (Fig. 44).

$\sigma^{\star}$ : unknown.

9 : posterior margin of tergite VIII weakly, that of sternite VIII moderately convex; spermatheca as in Fig. 45.

\section{Comparative notes:}

Among its Turkish consubgeners, the species is characterised especially by the combination of small size, oblong head, the presence of shallow microsculpture on head and pronotum, incrassate antennae with distinctly transverse preapical antennomers, the dense and granulosely punctured elytra, as well as the presence of punctures in the anterior impressions of the abdominal tergites III-V.

\section{Distribution and bionomics:}

So far only the two type specimens from the "Goek Dagh" and one additional specimen from Bolu in northwestern Anatolia have become known. The examined female syntype had two mature eggs in the ovaries.

\section{Aleochara (Ceranota) plicata LOKAY, 1907}

Aleochara (Ceranota) plicata LoKAY, 1907: 78 ff.

\section{Comments:}

The original description is based on two syntypes, a male and a female, from the environs of Adana, central southern Anatolia (LoKAY, 1907). The types were looked for, but not found in the collections of the natural history museum in Prague, where Lokay's material is deposited (FIKÁČEK, pers. comm.). According to the original description, the species is characterised especially by the modifications on the male abdominal tergites III-V and VII-VIII, which are illustrated by LOKAY (1907). 
Aleochara (Ceranota) bituberculata BeRnHAUER, 1900 (Figs 46-56)

Aleochara (Ceranota) bodemeyeri BeRnHAUER, 1900: $48 \mathrm{f}$.

\section{Type material examined:}

Holotype $0^{\top}$ : Asia minor, Sultan Dagh, v. Bodemeyer / bituberculata Brnh. ded. v. Bodemeyer / Type $\sigma^{*} /$ Chicago NHMus M.Bernhauer Coll. / Holotypus o* Aleochara bituberculata Bernhauer rev. V. Assing 2006 (FMNH).

Additional material examined: $1 \sigma^{\star}$ [aedeagus lost; identification uncertain], Kayseri, Erciyes Dağ $1,20 \mathrm{~km} \mathrm{~N}$ Develi, 30 km S Kayseri, 2500 m, alpine steppe with Artemisia, 1.VI.1993, leg. Schulz (cAss).

\section{Comments:}

The original description is explicitly based on a single specimen ("ein Stück") from the "Sultan Dagh in Kleinasien" (Bernhauer, 1900), so that the above type has holotype status.

Bernhauer (1900) originally described $A$. bituberculata as a distinct species, but subsequently considered it a variety of $A$. erythroptera Gravenhorst (Bernhauer, 1901). While Fagel (1968) attributed it the status of a distinct species again, Likovský (1973) confirmed the identity of $A$. bituberculata with $A$. erythroptera based on an examination of the aedeagus; however, when examining the aedeagus, he did not even remove the parameres, so that a proper assessment of its morphology was impossible. Although the taxonomic status of $A$. bituberculata does not seem to have been addressed since then, SMETANA (2004) again treats it as a valid species.

\section{Redescription:}

Measurements (in mm) and ratios (holotype): AL: 1.43; HL: 0.71; HW: 0.71; PW: 1.06; PL: 0.83; EL: 0.68; EW: 1.28; AW: 1.16; TiL: 0.83; TaL: 0.65; ML: 0.76; TL: 5.2; HL/HW: 1.00; PW/HW: 1.49; PW/PL: 1.27; EL/PL: 0.82; EW/PW: 1.21; AW/EW: 0.91; TiL/TaL: 1.28.

Coloration: head blackish brown; pronotum castaneous with reddish margins; elytra reddish yellow; abdomen dark brown, with posterior margins of segments III-VI, posterior $1 / 3$ of segment VII, and segments VIII-X reddish; legs reddish yellow; antennae dark reddish with antennomeres I-III yellowish.

Habitus as in Fig. 46. Head as wide as long (see ratio HL/HW); clypeus unmodified; puncturation fine and sparse; interstices without distinct microsculpture. Eyes moderately large, approximately as long as postocular region in dorsal view (Fig. 47). Antennae weakly incrassate; preapical antennomeres weakly transverse (Fig. 48).

Pronotum rather large and moderately transverse (see ratios PW/HW and PW/PL), widest approximately in the middle; puncturation similar to that of head; interstices without microsculpture (Fig. 47).

Elytra distinctly wider and at suture shorter than pronotum (see ratios EW/PW and EL/PL); posterior margin near posterior angles shallowly sinuate; puncturation dense and rather shallow, not granulose; microsculpture absent (Fig. 47). Metatarsus rather short and stout (see measurements); metatarsomere I approximately as long as the combined length of II-IV.

Abdomen with segments III-VI subparallel; tergites III-V with rather shallow anterior impressions, anterior impression of tergite VI very shallow; puncturation fine and rather sparse, very sparse in anterior impressions of tergite III-V; posterior margin of tergite VII with palisade fringe (Fig. 49). 


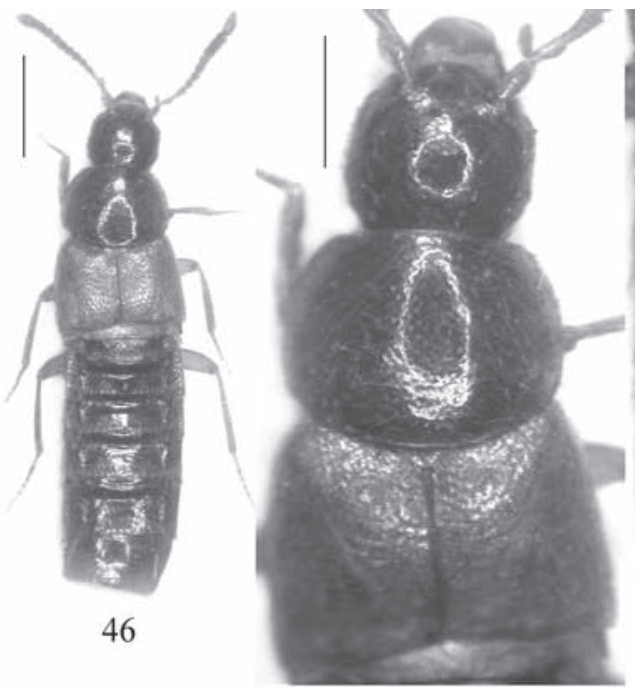

47

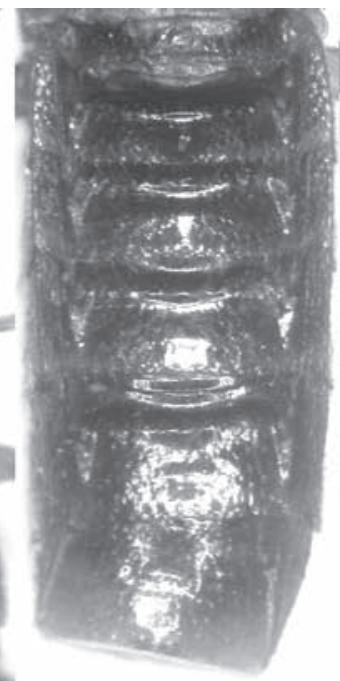

49
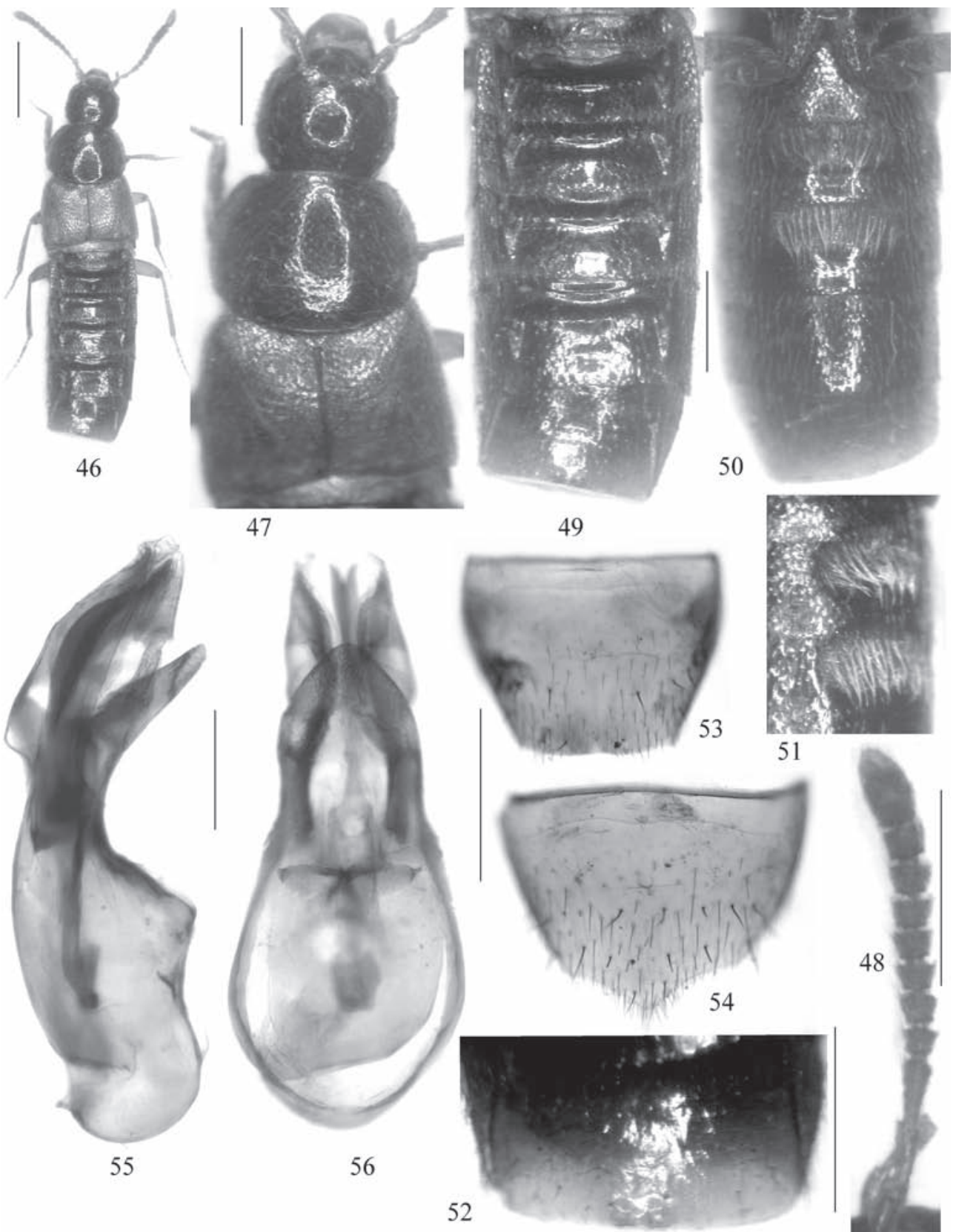

51

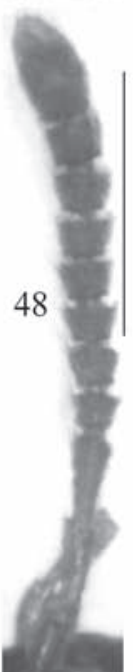

Figs 46-56: Aleochara bituberculata (holotype): habitus (46); forebody (47); antenna (48); abdomen (49); abdomen in ventral view (50); abdominal sternites IV-V in latero-ventral view (51); tergite VII (52); tergite VIII (53); sternite VIII (54); median lobe of aedeagus in lateral and in ventral view (55-56). Scale bars: 46: $1.0 \mathrm{~mm}$; 47-54: $0.5 \mathrm{~mm}$; 55-56: $0.2 \mathrm{~mm}$. 
$0^{\text {* }}$ : tergite III with subcircular median elevation near posterior margin (Fig. 47); tergite VII in the middle of posterior margin with two tubercles (Fig. 52); tergite VIII in the middle of the subtruncate posterior margin with pair of very indistinct elevations (Fig. 53); sternites IV and V with pronounced semicircular impressions with very dense long golden pubescence (similar to the condition in A. erythroptera) (Figs 50-51); posterior margin of sternite VIII distinctly pointed in the middle (Fig. 54); median lobe of aedeagus with rather stout ventral process both in lateral and in ventral view (Figs 55-56).

o: unknown.

\section{Comparative notes:}

Among its Turkish consubgeners, the species is characterised especially by the morphology of the aedeagus and by the modified male tergite VIII.

\section{Distribution:}

The identity of the type locality ("Sultan Dagh") probably refers to the Sultan Dağları crossing the border between Afyon and Isparta. FAGEL (1968) reported the species also from the Abant Dağları in Bolu, but his identifications are notoriously unreliable. The male from Kayseri listed above as additional material may refer to this species. Its external characters and especially its tergite VIII are similar to those of the holotype, but since the aedeagus is lost, the identification must be considered tentative.

\section{Aleochara (Ceranota) sp. 1}

Material examined: 1 우 , E Osmaniye, 1200-1700 m, leg. Schubert (NMW); 1 ㅇ , Kahramanmaraş, 50 km NW Kahramanmaraş, S Göksun, 3756N, 36³4E, 1380 m, 10.IV.2004, leg. Assing (cAss).

The above specimens probably represent an undescribed close relative of $A$. membranosa.

\section{Aleochara (Ceranota) sp. 2}

Material examined: 1 우 Kahramanmaraş, $10 \mathrm{~km} \mathrm{~N}$ Andırın, road to Çokak, 37³9N, 36 21E, $1150 \mathrm{~m}$, 1.-2.V.2005, leg. Brachat \& Meybohm (cAss); 1 ㅇ, Kahramanmaraş, 30 km W Kahramanmaraş, Başkonuş Yaylası, $37^{\circ} 34 \mathrm{~N}, 36^{\circ} 34 \mathrm{E}, 1270 \mathrm{~m}$, 27.IV.2005, leg. Besuchet (cAss).

The above specimens are somewhat similar to A. erythroptera, but distinguished especially by the longer and more massive antennae.

\section{Aleochara (Ceranota) sp. 3}

Material examined: 1 ㅇ, S Tatvan, 1700-2000 m, 21.V.-18.VI.1973, leg. Schubert (NMW).

This species is highly distinctive even based on external characters alone; it is characterised by very dark coloration (body black with the elytra dark reddish brown, antennae blackish brown; legs dark brown; maxillary palpus blackish brown) and by the conspicuously dense puncturation of the whole body.

\section{Aleochara (Ceranota) subtumida (Носннитн, 1849)}

Additional material examined: Izmir: 1 ex., Boz Dağlar, above Bozdağ, road to ski resort, $38^{\circ} 21 \mathrm{~N}, 28^{\circ} 07 \mathrm{E}$, 1500 m, N-slope, Alnus and Salix litter sifted, 3.IV.2006, leg. Wunderle (cWun). Bitlis: 1 ex., Tatvan, 1800 m, V.1976, leg. Schubert (NMW). 
In Turkey, the species was previously recorded from Zonguldak, Sinop, and Bitlis provinces (Assing, 2004, 2006b).

\section{Aleochara (Ceranota) erythroptera GravenHoRst, 1806 (Figs 57-73)}

Material examined: Muğla: $20^{\star} 0^{\star}, 1$ ㅇ, $70 \mathrm{~km}$ NE Fethiye, Seki, above Temel, $36^{\circ} 44 \mathrm{~N}, 29^{\circ} 34 \mathrm{E}, 2230 \mathrm{~m}$, near snow, 11.VII.2002, leg. Assing (cAss). Kars: 2 exs., 16 km SW Göle, 1600 m, 16.VI.1986, leg. Besuchet, Löbl \& Burckhardt (MHNG, cAss). Locality not specified: 1 ex., "Turcia”, leg. Merkl (NMW).

\section{Redescription:}

Measurements (in mm) and ratios (range, arithmetic mean; $\mathrm{n}=5$ ) of material from Turkey: AL: 1.25-1.71, 1.53; HL: 0.60-0.76, 0.69; HW: 0.59-0.70, 0.79; PW: 0.85-1.25, 1.09; PL: 0.660.94, 0.83; EL: 0.54-0.76, 0.66; EW: 1.07-1.51, 1.33; AW: 1.07-1.36, 1.26; TiL: 0.60-0.94, 0.86; TaL: 0.48-0.72, 0.63; ML: 0.68-0.71, 0.69; TL: 5.0-6.7, 5.9; HL/HW: 0.96-1.03, 0.98; PW/HW: 1.44-1.60, 1.53; PW/PL: 1.27-1.35, 1.31; EL/PL: 0.76-0.82, 0.80; EW/PW: $1.20-$ 1.27, 1.23; AW/EW: 0.90-1.00, 0.95; TiL/TaL: 1.29-1.44, 1.36

Coloration: head blackish; pronotum dark brown to black, often with the lateral margins of the pronotum reddish to reddish brown; elytra uniformly reddish yellow to dark reddish; abdomen black, with the posterior margins of segments III-VI, the posterior $1 / 3$ of segment VII, and segments VIII-X reddish to reddish brown; legs reddish to reddish yellow; antennae with antennomeres I-III yellowish and antennomeres IV-XI reddish to dark brown.

Head approximately as wide as long (see ratio HL/HW); clypeus unmodified; puncturation variable: dense and well-defined to moderately sparse, shallow and ill-defined; interstices with or without shallow microsculpture. Eyes approximately as long as postocular region in dorsal view (Fig. 57). Maxillary palpus slender, palpomere III approximately 3.5 times as long as wide. Antenna slender, apically weakly incrassate; preapical antennomeres weakly transverse (Fig. 58).

Pronotum large, distinctly wider than head and distinctly transverse (see ratios $\mathrm{PW} / \mathrm{HW}$ and $\mathrm{PW} / \mathrm{PL}$ ); maximal width in or behind middle; posterior angles weakly marked, almost completely rounded; puncturation variable, moderately sparse to very dense, fine to moderately coarse; interstices with or without shallow microreticulation (Fig. 57).

Elytra distinctly wider and at suture somewhat shorter than pronotum (see ratios EW/PW and $\mathrm{EL} / \mathrm{PL}$ ); posterior margins weakly sinuate near posterior angles; puncturation rather dense to very dense, usually well-defined, more distinct than that of head and pronotum; interstices with or without shallow microsculpture (Fig. 57). Hind wings fully developed. Legs moderately slender; metatarsus distinctly shorter than metatibia; metatarsomere I as long as the combined length of II-IV or nearly so.

Abdomen usually almost as wide as elytra; tergites III-V with moderately deep anterior impressions, anterior impression of tergite VI barely noticeable; puncturation relatively dense and distinct, impressions of tergites III-VI densely punctate (more so than remainder of tergal surfaces); integument glossy, with or without indistinct traces of microsculpture; posterior margin of tergite VII with palisade fringe (Fig. 59); tergites III and VII usually with distinct, tergite VIII with weakly pronounced sexual dimorphism.

$0^{\star}$ : tergite III with smooth subcircular or oval median elevation near posterior margin (Fig. 57); tergite VII at posterior margin with pair of tubercles or with bituberculate transverse ridge (Fig. 62); sternites IV and V in posterior halves with pronounced semicircular impressions with tomentose patches with dense long golden pubescence (Fig. 60-61); posterior margin of tergite 
VIII smooth and weakly convex (Fig. 68); posterior margin of sternite VIII pointed (Fig. 69); median lobe of aedeagus with slender ventral process (Figs 63-67).

\%: tergite and sternite VIII as in Figs 70-71; spermatheca of somewhat variable size and shape (Figs 72-73).
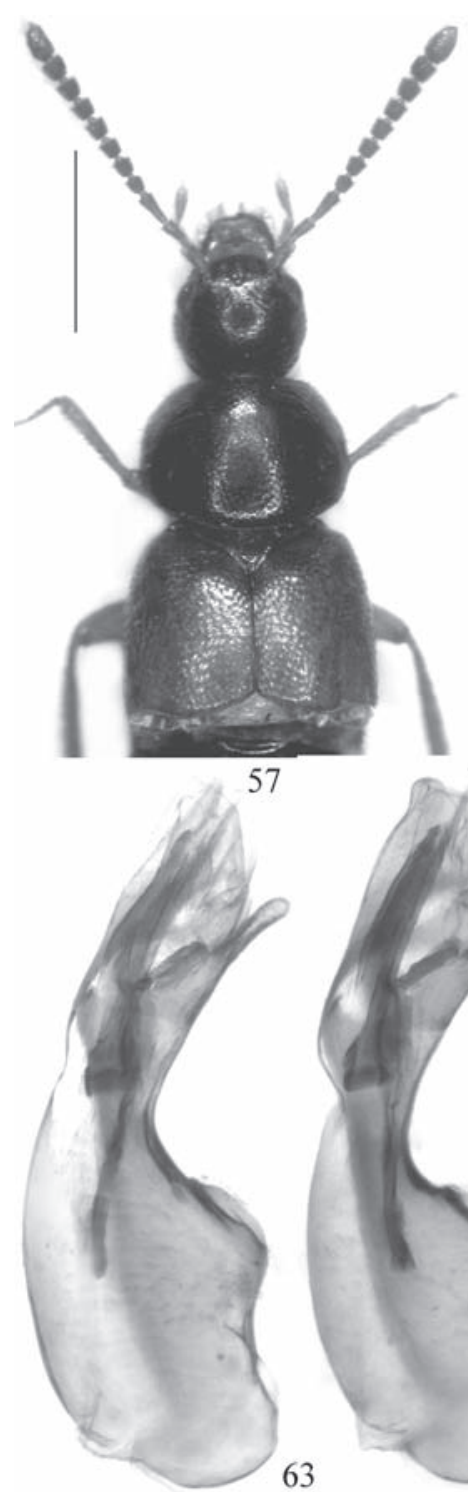

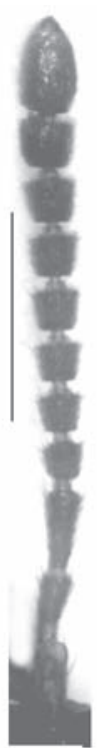

58

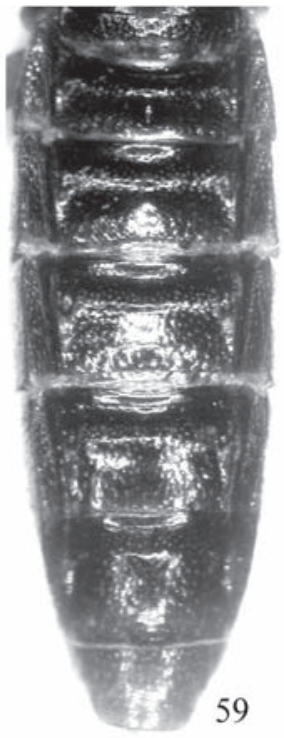

9
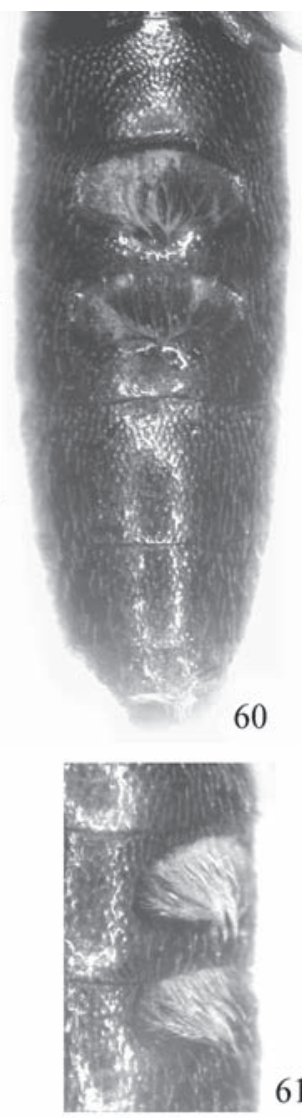

61

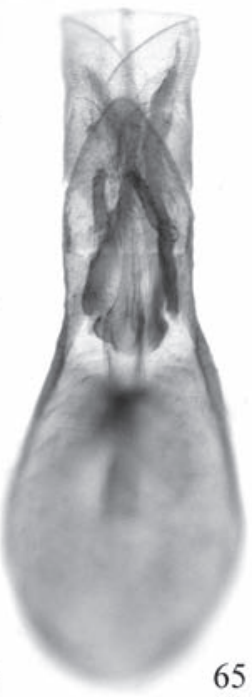

65

Figs 57-65: Aleochara erythroptera (males from Muğla): forebody (57); antenna (58); abdomen (59); abdomen in ventral view (60); abdominal sternites IV-V in latero-ventral view (61); tergite VII (62); median lobe of aedeagus in lateral and in ventral view (63-65). Scale bars: 57, 59-61: $1.0 \mathrm{~mm}$; 58, 62: $0.5 \mathrm{~mm}$; 63-65: $0.2 \mathrm{~mm}$. 


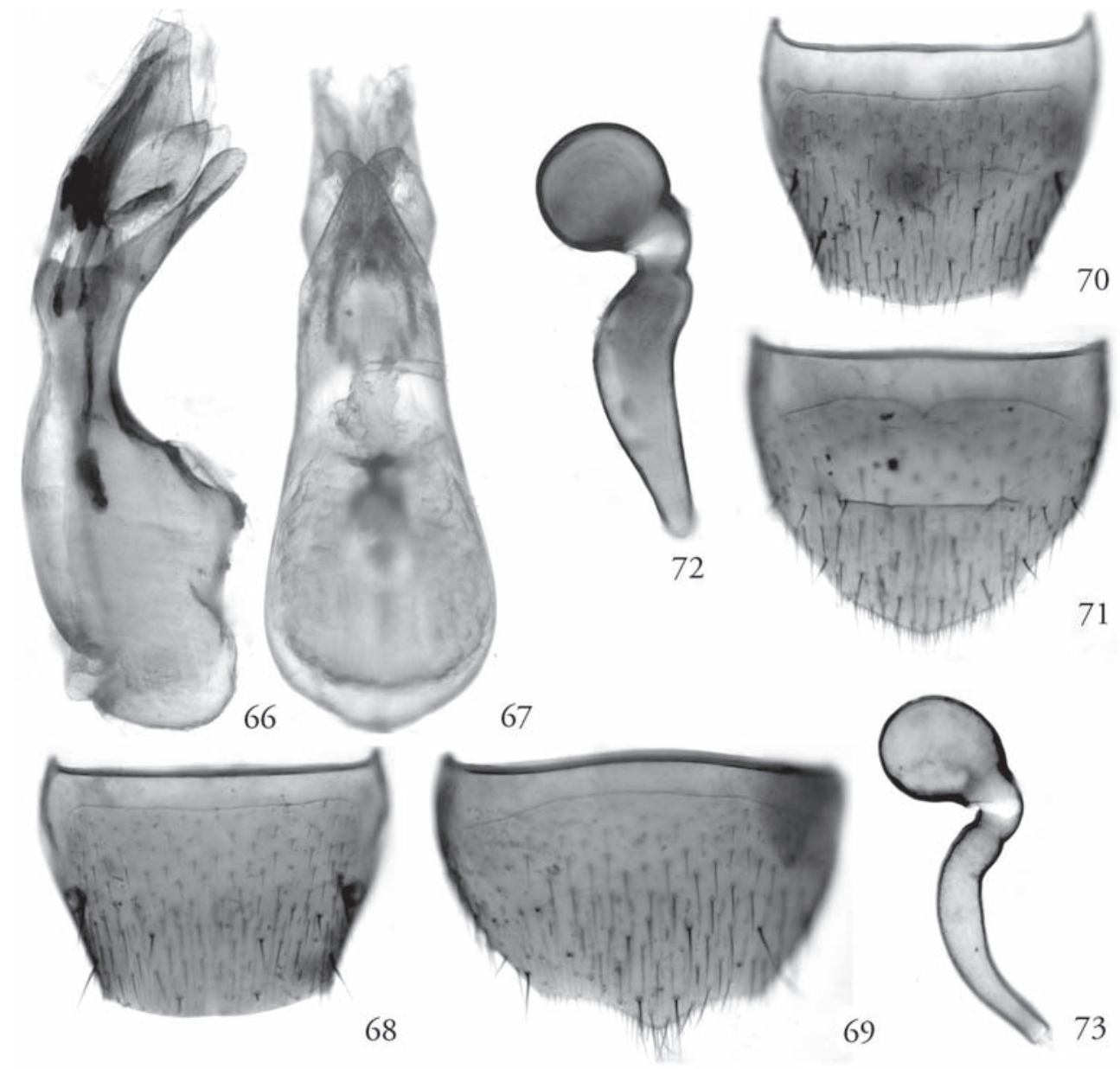

Figs 66-73: Aleochara erythroptera (66-67: Germany; 68-71, 73: Muğla; 72: Kars): median lobe of aedeagus in lateral and in ventral view (66-67); male tergite VIII (68); male sternite VIII (69); female tergite VIII (70); female sternite VIII (71); spermatheca (72-73). Scale bars: 68-71: 0.5 mm; 66-67, 72-73: $0.2 \mathrm{~mm}$.

Comments: As is usual in Aleochara species, size-related parameters are subject to considerable intraspecific variation. The specimens from Kars are distinguished from those from Muğla by shorter antennae, more distinct puncturation of head and pronotum, a somewhat larger pronotum (in relation to head), relatively larger elytra, and a larger spermatheca with a broader duct (Figs 72-73). However, no significant differences were observed in the male sexual characters. The material from Turkey differs from that seen from Central Europe by less dense puncturation of the pronotum and elytra, as well as by a somewhat more slender ventral process of the median lobe of the aedeagus (Figs 63-67). However, since these differences are only slight and no additional distinguishing characters were observed, they are here attributed to intra- rather than interspecific variation. 


\section{Comparative notes:}

Among other Ceranota species occurring in Turkey, A. erythroptera is identified especially by the slender median lobe of the aedeagus, the modifications of the male sternites IV-V (deep semicircular impressions with conspicuously dense tomentose pubescence), as well as by the combination of the following characters: slender antennae, dense puncturation of the elytra, and dense puncturation of the anterior impressions of the abdominal tergites III-VI.

\section{Distribution and bionomics:}

The species is widespread in central and southern Europe and has also been reported from Turkey without specification of the locality (Ganglbauer, 1895; Horion, 1967; Smetana, 2004). Bernhauer (1901) only reported $A$. bituberculata, which he regarded as a variety of $A$. erythroptera, from Turkish territory. Recent records were unknown. The specimens from Muğla were sifted from debris and roots near snowfields at an altitude of more than $2200 \mathrm{~m}$; the material from Kars was collected at an elevation of $1600 \mathrm{~m}$. For more details regarding the life history of this species see Assing (1994).

\section{Aleochara (Ceranota) cf. erythroptera (Figs 74-83)}

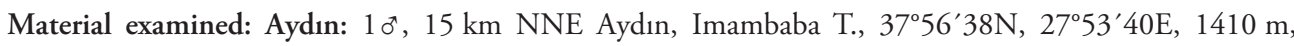
5.IV.2006, leg. Wunderle (cWun).

Comments: The above specimen is a small male. Measurements (in mm) and ratios: AL: 1.13; HL: 0.53; HW: 0.56; PW: 0.76; PL: 0.60; EL: 0.45; EW: 0.92; AW: 0.91; TiL: 0.59; TaL: 0.47; ML: 0.59; TL: 4.1; HL/HW: 0.95; PW/HW: 1.35; PW/PL: 1.25; EL/PL: 0.75; EW/PW: 1.22; AW/EW: 0.98; TiL/TaL: 1.26.

The specimen is characterised by a relatively large head (in relation to the pronotum) (Figs 7475), relatively short antennae (Fig. 76), the weakly transverse pronotum (Fig. 75), very sparse puncturation of the abdomen (Fig. 76), and shallow impressions with tomentose pubescence on the male sternites IV and V (Figs 77-78). The aedeagus is somewhat smaller than is usually the case in A. erythroptera seen from Turkey, but otherwise identical (Figs 82-83). Based on the similarity of the male primary sexual characters, the specimen is here tentratively attributed to A. erythroptera, despite the observed differences in the external differences, especially in the puncturation of the abdomen.

\section{Aleochara (Coprochara) bilineata Gylenhal, 1810}

Material examined: Gümüşhane: 1 ex., E Zigana Geçidi, ca. 40³7N, 39²5E, 2400 m, 10.VI.1998, leg. Solodovnikov (cAss). Artvin: 1 ex., Borçka, 1500 m, VI.1972, leg. Schubert (NMW).

This cosmopolite had been reported from Turkey before, but without specifications of localities.

\section{Aleochara (Coprochara) bipustulata (LinNAEus, 1760)}

Material examined: Ordu: 1 ex., $25 \mathrm{~km} \mathrm{~S}$ Ordu, S Kabaduz, 4049N, 3754E, $990 \mathrm{~m}$, mixed forest, 30.VII.2006, leg. Assing (cAss). Gümüşhane: 1 ex., ca. $80 \mathrm{~km} \mathrm{SW} \mathrm{Trabzon,} \mathrm{Zigana} \mathrm{Geçidi,} \mathrm{4037N,}$ $39^{\circ} 24 \mathrm{E}, 2050 \mathrm{~m}$, roots of grass, moss, and shrubs sifted, 23.VII.2006, leg. Assing (cAss); 1 ex., E Zigana Geçidi., ca. $40^{\circ} 37 \mathrm{~N}, 39^{\circ} 25 \mathrm{E}, 2400 \mathrm{~m}, 10 . \mathrm{VI} .1998$, leg. Solodovnikov (cAss). Rize: 1 ex., ca. $30 \mathrm{~km} \mathrm{~S}$ Ardeşen, $40^{\circ} 56 \mathrm{~N}, 40^{\circ} 58 \mathrm{E}, 750 \mathrm{~m}$, moist forest, sifted, 3.VIII.2006, leg. Assing (cAss); 1 ex., ca. $30 . \mathrm{km}$ SW Hopa, Çağlayan D. river valley, ca. $41^{\circ} 09 \mathrm{~N}, 41^{\circ} 22 \mathrm{E}, 1300 \mathrm{~m}, 28$. VI.1998, leg. Solodovnikov (cAss). Izmir: 1 ex., Boz Dağlar, Bozdağ, 1200-1500 m, 29.V.-1.VI.2003, leg. Smatana (cSch). Muğla: 1 ex., 30 km 


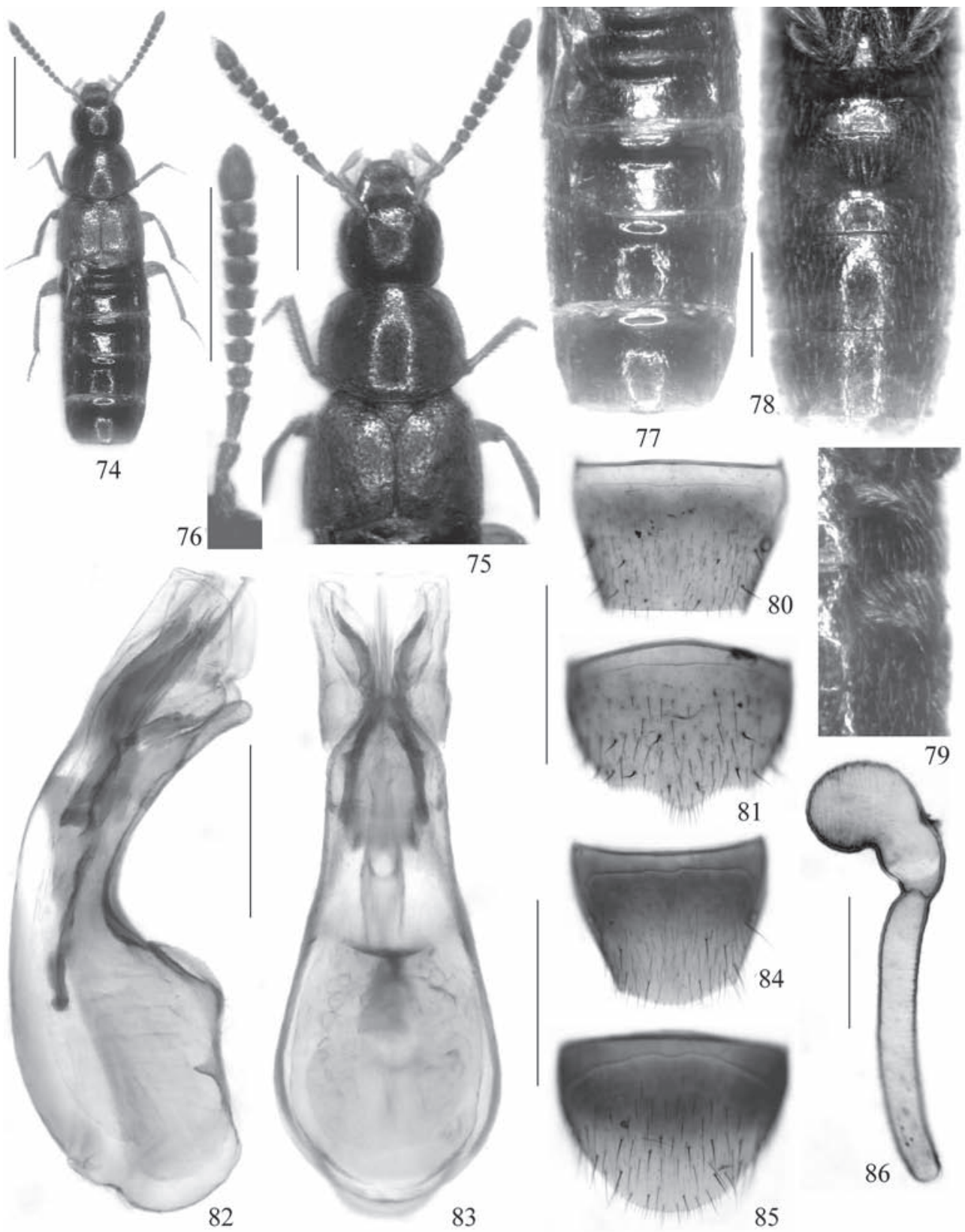

Figs 74-86: Aleochara cf. erythroptera, nanistic male (74-83) and A. caloderoides (84-86): habitus (74); forebody (75); antenna (76); male abdomen (77); male abdomen in ventral view (78); male sternites IV-V in latero-ventral view (79); male tergite VIII (80); male sternite VIII (81); median lobe of aedeagus in lateral and in ventral view (82-83); female tergite VIII (84); female sternite VIII (85); spermatheca (86). Scale bars: 74: $1.0 \mathrm{~mm}$; 75-81, 84-85: $0.5 \mathrm{~mm}$; 82-83: $0.2 \mathrm{~mm}$; $86: 0.1 \mathrm{~mm}$. 
NE Fethiye, Boncuk Dağı, Koru, 36 51 N, 29¹4E, 1750 m, 8.X.2002, leg. Assing (cAss). Antalya: 1 ex., N Kalkan, Dumanlı Dağı, 36 24Nm, 29 26E, 1230 m, pasture, 5.X.2002, leg. Assing (cAss). Niğde: 1 ex., Ulukişla, Maden köy env., Bolkar Dağları, 1700-2000 m, 13.-15.VI.2003, leg. Lohaj (cAss). Konya: 2 exs., Aksehir env., Sultan Dağları, 14.\&16.V.1960, leg. Petrowitz \& Ressl (NMW, cAss). Antakya: 1 ex., 25 km

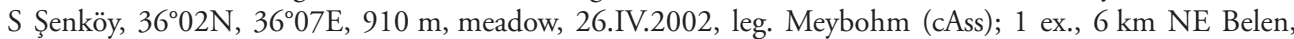
$36^{\circ} 32 \mathrm{~N}, 36^{\circ} 15 \mathrm{E}, 1480 \mathrm{~m}, 4 . I V .2004$, leg. Schülke (cSch); 1 ex., Iskenderun, 9.IV.1960, leg. Petrowitz \& Ressl (NMW).

This species is widespread and common throughout the Palaearctic region.

\section{Aleochara (Coprochara) verna SAY, 1833}

Material examined: Erzurum: 1 ex., 35-40 km NW Tortum, Mescit Dağları, ca. 4030N, 41¹7E, 2600 m, 19.VI.1998, leg. Solodovnikov (cAss). Kahramanmaraş: 1 ex., $10 \mathrm{~km} \mathrm{~N}$ Andırın, road to Çokak, 37³9N, 36 21E, 1150 m, 1.-2.V.2005, leg. Brachat \& Meybohm (cAss). Gaziantep: 2 exs., Nurdağ 1 Geç., 20 km N Islahiye, 1200 m, 12.V.1997, leg. Schulz, Vock \& Sanetra (cAss).

This species is widespread and common throughout the Palaearctic region.

\section{Aleochara (Dyschara) inconspicua AUBÉ, 1850}

Material examined: Antalya: 2 exs., 35 km NNE Alanya, NE Gündoğmus, Osman Dağı, 36 $51 \mathrm{~N}, 32^{\circ} 04 \mathrm{E}$, $1480 \mathrm{~m}$, stony meadow, grass sifted, 25.XII.2006, leg. Assing (cAss). Osmaniye: 1 ex., Osmaniye, 12001700 m, leg. Schubert (cAss). Mardin: 1 ex., Mardin, 1300 m, V.1969, leg. Schubert (NMW).

The species was only recently reported from Turkey for the first time (Assing, 2006b, 2007).

\section{Aleochara (Heterochara) clavicornis REDTENBACHER, 1849}

Material examined: Antakya: 2 exs., Iskenderun, 9.IV.1960, leg. Petrowitz \& Ressl (NMW, cAss). Kahramanmaraş: 1 ex., Elbistan, Nurhak, 2000 m, 5.VI.1965, leg. Schubert (NMW).

This cosmopolite was previously unknown from Turkey.

\section{Aleochara (Heterochara) spissicornis ERICHSON, 1839}

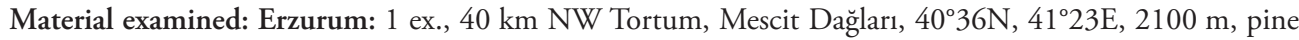
forest, 20.VI.1998, leg. Solodovnikov (cAss). Konya: 1 ex., Akşehir env., Sultan Dağları, 24.IV.1960, leg. Petrowitz \& Ressl (NMW). Mersin: 1 ex., Çamlıyayla-Meşelik, 3706N, 3442E, 920 m, 5.V.2002, leg. Brachat \& Meybohm (cAss).

According to Smetana (2004), this rare species has a trans-Palaearctic distribution and had been reported from Turkey before.

\section{Aleochara (Rheochara) spadicea ERICHSON, 1837}

Material examined: Muğla: 1 ex., 60 km NE Fethiye, Temel - Girdev Gölü, 3644N, 29³9E, 1935 m, grass roots sifted, 3.X.2002, leg. Assing (cAss).

The species had been reported from Turkey (SMETANA, 2004), but without specification of localities. 

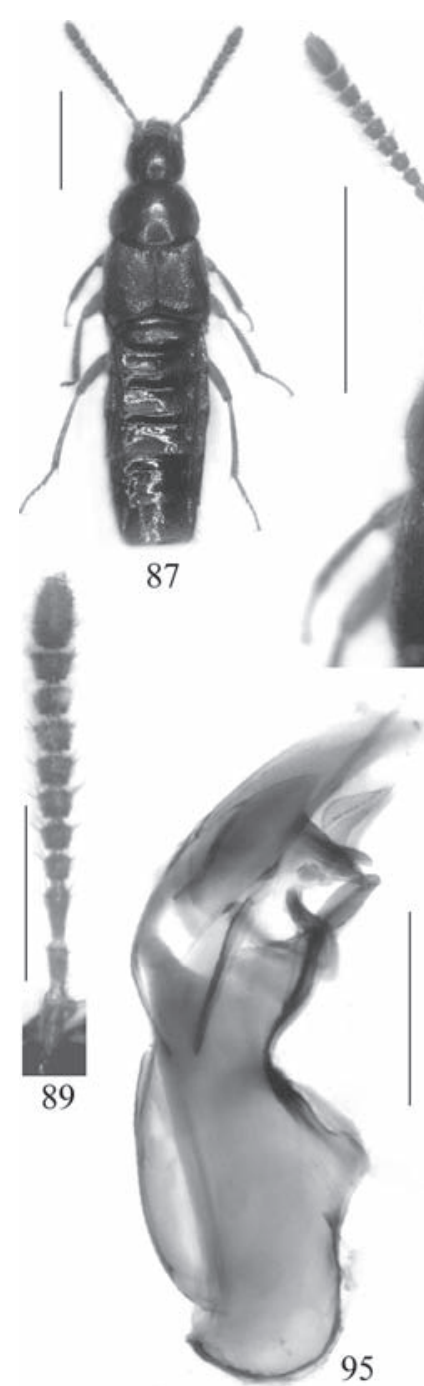

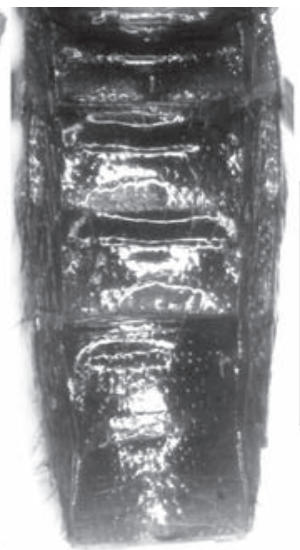

90

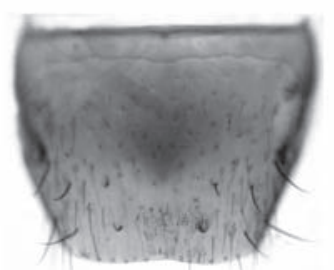

93
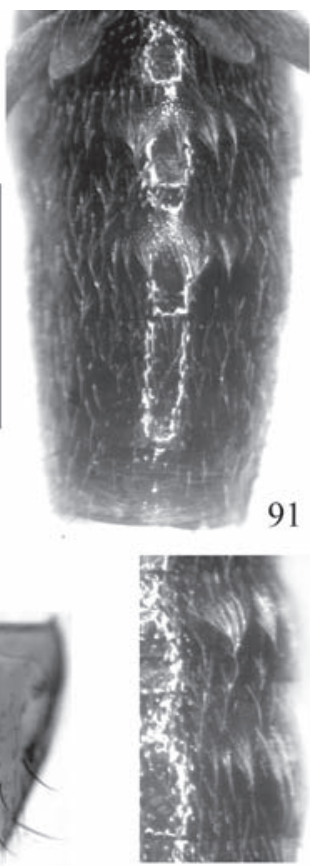

92

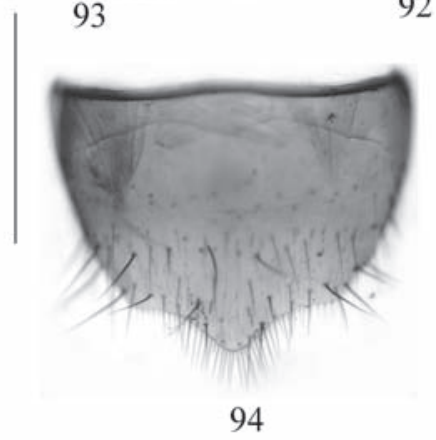

96

Figs 87-96: Aleochara caucasica ("Swanetien, Leder. Reitter", coll. Bernhauer): habitus (87); forebody (88); antenna (89); male abdomen (90); male abdomen in ventral view (91); male sternites IV-V in latero-ventral view (92); male tergite VIII (93); male sternite VIII (94); median lobe of aedeagus in lateral and in ventral view (95-96). Scale bars: 87-88, 90-92: $1.0 \mathrm{~mm}$; 89, 93-94: $0.5 \mathrm{~mm}$; 95-96: $0.2 \mathrm{~mm}$.

\section{Aleochara (Rheochara) leptocera EPPELSHEIM, 1889 (Figs 97-98)}

Aleochara (Baryodma) leptocera Eppelsheim, 1889: $167 \mathrm{f}$.

Type material examined: Neotype + : $\uparrow /$ El Ramleh, Nest von Spalax Ehrenbergi / Palästina, Israel / leptocera Epp / ex coll. Scheerpeltz / Neotypus Rheochara leptocera Epp. / Aleochara leptocera Eppelsheim det. V. Assing 2007 (NMW).

"Holotype": Turcia Merkl / c. Eppelsh. Steind. d. / leptocera Fauv. var. minor / 21 / leptocera Epp. Deutsch. ent. Zeit. 1889 p. 167 / Typus / Dieses Ex. wurde so von Dr. Likovsky zurückgesendet / Aleochara spadicea Erichson det. V. Assing 2007 (NMW). 


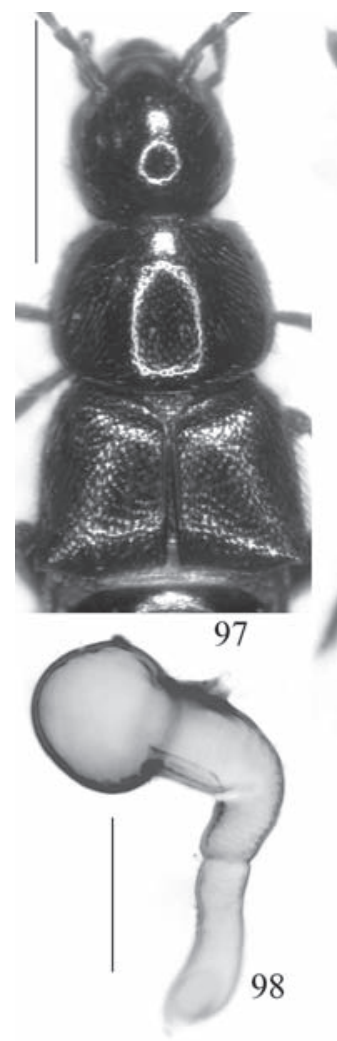

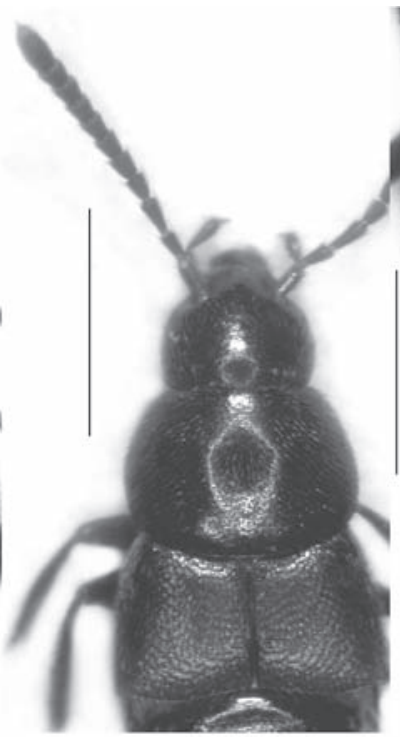

99

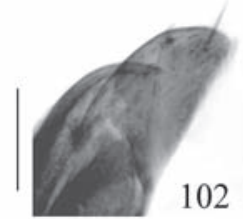

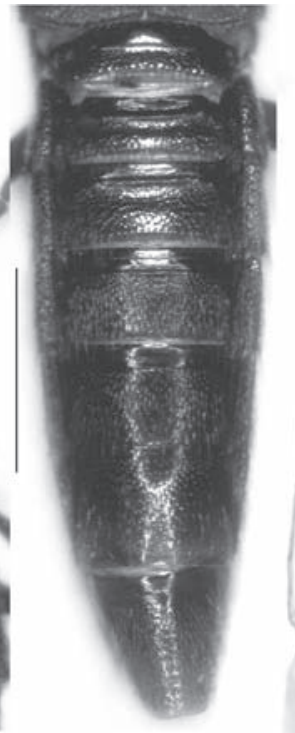

100

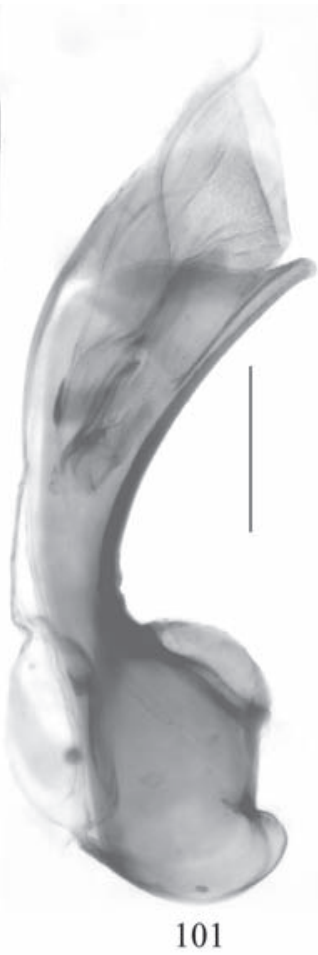

Figs 97-102: Neotype of Aleochara leptocera (97-98) and lectotype of A. spalacis (99-102): forebody (97, 99); spermatheca (98); abdomen (100); median lobe of aedeagus in lateral view (101); apical lobe of paramere (102). Scale bars: 97, 99-100: $1.0 \mathrm{~mm}$; 101: $0.2 \mathrm{~mm}$; 98, 102: $0.1 \mathrm{~mm}$.

\section{Comments:}

The original description of $A$. leptocera is based on a single holotype specimen "von der türkischen Ausbeute Merkl's" (Eppelsheim, 1889). In a key to the species of Rheochara, Scheerpeltz (1969a) gave a diagnosis of $A$. leptocera. In the same year, ScheErpeltz (1969b) published a short supplement to this paper, which he dedicated entirely to the type of A. leptocera. As stated in the supplement, the holotype had been loaned out to Z. Likovský, but instead of returning the original specimen, he had mounted a small damaged specimen of $A$. spadicea on the pin. According to Scheerpeltz (1969b), all subsequent attempts at retrieving the original specimen failed, so that a neotype was designated. Unfortunately, this neotype is a female. In external appearance, it resembles a large dark specimen of $A$. spadicea, but the pronotum is more finely punctate than is usually the case in $A$. spadicea (Fig. 97). In addition, the spermathecal duct is of slightly different shape (Fig. 98).

There is little chance that it will ever become clear if the neotype is really conspecific with the original holotype of $A$. leptocera. Consequently, the presence of this species in Turkey is currently doubtful. 
Aleochara (Rheochara) spalacis (SCHEERPELTZ, 1969) (Figs 99-102)

Rheochara spalacis SCHEERPELTZ, 1969: $119 \mathrm{ff}$.

Type material examined: Lectotype $\sigma^{\star}$, here designated: 우 [sic] / El Ramleh, Nest von Spalax Ehrenbergi / Palästina, Israel / Aleochara spalacis nov. spec. / ex coll. Scheerpeltz / Typus Aleochara spalacis O. Scheerpeltz / Lectotypus ơ Rheochara spalacis Scheerpeltz desig. V. Assing 2007 / Aleochara spalacis (Scheerpeltz) det. V. Assing 2007 (NMW). Paralectotypes: $10^{\star}$ : same data as lectotype, but " $\sigma^{\text {" }}$ " (NMW); $10^{\star}$, same data as lectotype, but " 0 " ... "Cotypus" (NMW).

\section{Comments:}

The original description is based on an unspecified number of syntypes ("einige Exemplare") from "Palästina (Umg. El Ramleh)" (Scheerpeltz, 1969). One of the three syntypes in the Scheerpeltz collection (NMW), all of them males, is here designated as the lectotype. Its forebody, abdomen, median lobe of the aedeagus, and apical lobe of the paramere are illustrated in Figs 99-102.

The species is apparently nidicolous and was found in the nest of the Eurasian mole rat. Since this mammal is possibly more widespread, A. spalacis may also be present in Turkey.

\section{Aleochara (Xenochara) cuniculorum KRAATZ, 1864}

Material examined: Konya: 1 ex., Seydişehir env., 1400 m, 5.-6.VI.2003, leg. Smatana (cAss).

According to Smetana (2004), the distribution of this species ranges from the western Mediterranean to Mongolia. It is here reported from Turkey for the first time.

\section{Aleochara (Xenochara) discipennis Mulsant \& REY, 1853}

Material examined: Istanbul: 1 ex., Ömerli-Şile, 18.V.1987, leg. Schönmann \& Schillhammer (cAss). Mersin: 1 ex., Çamliyayla, 1800 m, V.1963, leg. Schubert (NMW).

The species is widespread in Europe, but had not been recorded from Turkey (SMEtana, 2004).

\section{Aleochara (Xenochara) funebris Wollaston, 1864}

Material examined: Konya: 1 ex., Seydişehir env., 1400 m, 5.-6.VI.2003, leg. Smatana (cAss); 3 exs., Beyşehir Gölü, Haci Akil Mağara, 10.-12.VI.2003, leg. Smatana (cAss, cSch).

Aleochara funebris is widespread in the Palaearctic and the Oriental regions, but had been unknown from Turkey (Smetana, 2004).

\section{Aleochara (Xenochara) haematoptera KRAATZ, 1858}

Material examined: Istanbul: 1 ex., Ömerli-Şile, 18.V.1987, leg. Schönmann \& Schillhammer (NMW). Amasya: 3 exs., Taşova-Ladik, 10.VII.1996, leg. Bayer \& Winkelmann (cAss, cSch); 1 ex., Boraboy near Amasya, 26.-31.V.1961, leg. Schubert (NMW). Sinop: 1 ex., Çaykaşı river, Erfelek, 26.V.1989, leg. Schönmann \& Schillhammer (NMW). Trabzon: 1 ex., ca. $40 \mathrm{~km} \mathrm{~S}$ Of, S Uzungöl, $40^{\circ} 36 \mathrm{~N}, 40^{\circ} 17 \mathrm{E}$, 2050 m, 4.VIII.2006, leg. Assing (cAss). Niğde: 3 exs., Ulukişla, Maden köy env., Bolkar Dağları, 17002000 m, 13.-15.VI.2003, leg. Lohaj, Smatana (cAss, cSch). Tunceli: 10 ex., Ovacık, 1400 m, VI.1976, leg. Schubert (NMW, cAss). Kahramanmaraş: 1 ex., $10 \mathrm{~km} \mathrm{~N}$ Andırın, road to Çokak, 37³9N, 36 21E, 1150 m, 1.-2.V.2005, leg. Brachat \& Meybohm (cAss); 1 ex., Elbistan, Nurhak, 2000 m, 5.VI.1965, leg. Schubert (cAss); 1 ex., Elbistan, 26.-30.V.1966, leg. Schubert (NMW). Osmaniye: 1 ex., E Osmaniye, 1200-1700 m, leg. Schubert (NMW). Antakya: 1 ex., Yenioba, 26.V.1987, leg. Schönmann \& Schill- 
hammer (NMW). Siirt: 3 exs., E Sirnak, 31.V.1987, leg. Schönmann \& Schillhammer (NMW, cAss); 1 ex., Yayladağı-Yeditepe, 23.V.1987, leg. Schönmann \& Schillhammer (NMW). Bitlis: 1 ex., S Tatvan, 1700-2000 m, 21.V.-18.VI.1973, leg. Schubert (NMW). Van: 1 ex., Güzeldere Geçidi, 5.VI.1987, leg. Schönmann \& Schillhammer (NMW).

This cosmopolite had been known from Turkey (SMETANa, 2004), but without specified localities.

\section{Aleochara (Xenochara) ignipennis FAUVEL, 1900}

Material examined: Bitlis: 1 ex., Tatvan, 1900 m, 20.V.1969, leg. Schubert (NMW).

The species was recently recorded from Turkey (Adana province) for the first time (Assing, 2007).

\section{Aleochara (Xenochara) laevigata Gyllenhal, 1810}

Material examined: Gümüşhane: 1 ex., ca. $50 \mathrm{~km} \mathrm{SW}$ Trabzon, E Zigana Geçidi, ca. 40³7N, 39²6E, 2500 m, 11.VI.1998, leg. Solodovnikov (cAss). Urfa: 1 ex., Halfeti, 27.V.1987, leg. Schönmann \& Schillhammer (NMW). Bitlis: 1 ex., S Tatvan, 1700-2000 m, 26.-29.VI.1975, leg. Schubert (NMW); 34 exs., S Tatvan, 1700-2000 m, 21.V.-18.VI.1973, leg. Schubert (NMW; cAss). Van: 1 ex., E Van lake, 18002200 m, VI.1971, leg. Schubert (cAss).

According to Smetana (2004), A. laevigata is widespread in practically all of the Palaearctic region.

\section{Aleochara (Xenochara) lanuginosa GravenHorst, 1802}

Material examined: Osmaniye: 1 ex., Osmaniye, 300 m, VI.1968, leg. Schubert (NMW).

This widespread Palaearctic species had been reported from Turkey before (SMETANA, 2004).

\section{Aleochara (Xenochara) lygaea KRAATZ, 1862}

Material examined: Artvin: 1 ex., Borçka, VII.1974, leg. Schubert (NMW); 1 ex., Borçka, 1500 m, VI.1972, leg. Schubert (cAss). Tunceli: 6 exs., Ovacık, 1400 m, VI.1976, leg. Schubert (NMW, cAss). Bitlis: 4 exs., Bitlis, 1800 m, 28.V.1969, leg. Schubert (NMW, cAss).

The species has a trans-Palaearctic distribution, but was previously unknown from Turkey (Smetana, 2004).

\section{Aleochara (Xenochara) maculipennis BAUDI, 1857}

Material examined: Kahramanmaraş: 1 ex., Elbistan, Nurhak, 2000 m, 5.VI.1965, leg. Schubert (NMW). Urfa: 2 exs., Halfeti, 27.V.1987, leg. Schönmann \& Schillhammer (NMW). Hakkâri: 1 ex., Şemdinli, 1500 m, VI.1976, leg. Schubert (NMW).

This species was only recently reported from Turkey (Konya) for the first time (Assing, 2007). 


\section{Aleochara (Xenochara) moesta GRAVENHORST, 1802}

Aleochara (Isochara) ebneri SCHEERPELTz, 1929: 246 ff.; syn. n.

Type material examined: Holotype †: Khudeira b. Haifa, Palästina, 14-16.VII., R. Ebner 1928 / Unter Kuhfladen / 15.VII.1928 / Photographiert 28.XII.28 O. Scheerpeltz / ex coll. Scheerpeltz / Typus Aleochara Ebneri O. Scheerpeltz / Aleochara moesta Gravenhorst det. V. Assing 2007 (NMW).

Additional material examined: Tunceli: 1 ex., Ovacık, 1400 m, VI.1976, leg. Schubert (NMW). Bitlis: 1 ex., Tatvan, 1900 m, 20.V.1969, leg. Schubert (cAss). Van: 2 exs., E Van lake, 1800-2200 m, VI.1971, leg. Schubert (NMW). Locality not identified: 1 ex., Kaliovar, 17.VI.1974, leg. Schubert (NMW).

The original description of $A$. ebneri is based on a single holotype female from "Khudeira bei Haifa" (ScheERpeltz, 1929). An examination of this specimen, including a dissection of the spermatheca, revealed that it is a small pale specimen of $A$. moesta; hence the synonymy proposed above.

Aleochara moesta was only recently reported from Turkey (Konya) for the first time (Assing, 2007).

\section{Aleochara (Xenochara) puberula KLUG, 1832}

Material examined: Osmaniye: 2 exs., Osmaniye, 300 m, VI.1968, leg. Schubert (NMW, cAss).

This cosmopolite had been recorded from Turkey (SMETAnA, 2004), but without specified localities.

\section{Aleochara (Xenochara) sparsa HeER, 1839}

Material examined: Istanbus: 1 ex., "Belgrader Wald”, 1.-7.VII.1954, leg. Schubert (NMW).

This widespread and common species was only recently reported from Turkey (Rize) for the first time (Assing, 2007).

\section{Aleochara (Xenochara) tristis GrAVENHORST, 1806}


2500 m, 14.VI.1998, leg. Solodovnikov (cAss). Artvin: 1 ex., ca. $40 \mathrm{~km} \mathrm{SW} \mathrm{Artvin,} \mathrm{source} \mathrm{of} \mathrm{Barhal} \mathrm{river,}$ ca. $41^{\circ} 05$ N , 41ํํㄹ, 2400-2800 m, 24.VI.1998, leg. Solodovnikov (cAss). Konya: 2 exs., Beyşehir, Çamlık env., 29.IV.-1.V.2001, leg. Lohaj, Smatana (cAss); 1 ex., Akşehir env., Sultan Dağları, 26.IV.1960, leg. Petrowitz \& Ressl (NMW); 2 exs., same data, but 4.V.1960 (NMW, cAss); 1 ex., same data, but 16.V.1960 (NMW); 1 ex., Akşehir, 19.V.1960 leg. Petrowitz \& Ressl (NMW). Mersin: 1 ex., Çamlıyayla, IV.1976, leg. Schubert (NMW). Osmaniye: 1 ex., Osmaniye, 1100 m, V.-VI.1967, leg. Schubert (cAss); 1 ex., Osmaniye, 1200 m, VI.1967, leg. Schubert (NMW); 1 ex., Osmaniye, 1.V.1976, leg. Schubert (NMW). Antakya: 2 exs., Iskenderun, 9.IV.1960, leg. Petrowitz \& Ressl (NMW, cAss). Kahramanmaraş: 1 ex., Elbistan, 26.V.6.VI.1965, leg. Schubert (NMW); 1 ex., Elbistan, 26.-30.V.1966, leg. Schubert (NMW); 1 ex., Elbistan, Nurhak, 2000 m, 29.V.1966, leg. Schubert (cAss). Gaziantep: 1 ex., Nurdağı Geçidi, 20 km N Islahiye, 1200 m, 12.V.1997, leg. Schulz, Vock \& Sanetra (cAss). Urfa: 1 ex., Urfa, 600 m, V.1976, leg. Schubert (NMW). Mardin: 1 ex., Midiyat, 30.V.1987, leg. Schillhammer (NMW). Malatya: 3 exs., $90 \mathrm{~km} \mathrm{SE}$ Malatya, Nohutlu, ca. 1700 m, 5.-9.VI.1993, leg. Schröder (cAss). Bitlis: 9 exs., Tatvan, 1900 m, 20.V.1969, leg. Schubert (NMW, cAss); 2 exs., Tatvan, 1700-2000 m, 21.V.-18.VI.1973, leg. Schubert (NMW, cAss). Locality not identified: Karliovar, VI.1974, leg. Schubert (NMW).

This cosmopolite had been known from Turkey (Smetana, 2004), but without specified localities. 


\section{Checklist of the Aleocharini of Turkey}

The list of references is not complete, but confined to major catalogues, primary records, and some additional works dealing specifically with the taxonomy of Aleochara. In many cases, especially the older literature offers only general records ("Türkei”, "Kleinasien"/"Asia Minor", etc.) without specification of the precise locality. The primary records of some species were not found. Only the valid names and the synonymies established in the present paper are listed in the checklist; for additional synonymies see Smetana (2004).

\begin{tabular}{|c|c|c|}
\hline Taxon & Turkish provinces & References \\
\hline \multicolumn{3}{|l|}{ Pseudocalea Luze, 1902} \\
\hline P. angulata Eppelsheim, 1880 & Istanbul, Mersin & $\begin{array}{l}\text { Assing (present paper), } \\
\text { BERnHAUER (1902), } \\
\text { SMETANA (2004) }\end{array}$ \\
\hline P. korbi (Bernhauer, 1902) & ? & $\begin{array}{l}\text { Assing (2002), } \\
\text { Assing (2007), } \\
\text { BERNHAUER (1902), } \\
\text { SMETANA (2004) } \\
\end{array}$ \\
\hline P. messorphila Assing, 2007 & Izmir & Assing (2007) \\
\hline \multicolumn{3}{|l|}{ Tinotus SHaRP, 1883} \\
\hline T. morion (GRAVENHORST, 1802) & Mersin & Assing (present paper) \\
\hline \multicolumn{3}{|l|}{ Megalogastria BERNHAUER, 1901} \\
\hline M. cingulata (EPPELSHeim, 1889) & Istanbul, Izmir, Muğla & $\begin{array}{l}\text { Assing (2007), } \\
\text { BERNHAUER (1901), } \\
\text { BERNHAUER \& SCHEERPELTZ (1926), } \\
\text { EPPELSHEIM (1889), } \\
\text { SMETANA (2004) }\end{array}$ \\
\hline M. alata sp. n. & Bitlis, Erzurum & Assing (present paper) \\
\hline \multicolumn{3}{|l|}{ Aleochara Gravenhorst, 1802} \\
\hline A. (Aleochara) curtula (Goeze, 1977) & $\begin{array}{l}\text { Ardahan, eastern Anatolia } \\
\text { ("Korkha") }\end{array}$ & $\begin{array}{l}\text { Assing (present paper), } \\
\text { PEyron (1858), } \\
\text { SCHEERPELTZ (1958), } \\
\text { SMETANA (2004) }\end{array}$ \\
\hline A. (Aleochara) egregia ApFelBeCK, 1906 & Istanbul? & SMETANA (2004) \\
\hline A. (Aleochara) lata Gravenhorst, 1802 & ? & $\begin{array}{l}\text { BERNHAUER (1901), } \\
\text { BERNHAUER \& SCHEERPELTZ (1926), } \\
\text { Horion (1967), } \\
\text { SMETANA (2004) }\end{array}$ \\
\hline A. (Aleochara) laticornis KRAATZ, 1856 & $\begin{array}{l}\text { Antalya, Konya, Mersin, } \\
\text { Antakya }\end{array}$ & $\begin{array}{l}\text { Assing (present paper), } \\
\text { BERNHAUER (1901), } \\
\text { BERNHAUER \& SCHEERPELTZ (1926), } \\
\text { HORION (1967), } \\
\text { SCHEERPELTZ (1960), } \\
\text { SMETANA (2004) }\end{array}$ \\
\hline
\end{tabular}




\begin{tabular}{|c|c|c|}
\hline Taxon & Turkish provinces & References \\
\hline A. (Baryodma) intricata MANNERHEIM, 1830 & $\begin{array}{l}\text { Istanbul, Konya, Ankara, } \\
\text { Rize, Artvin, Mersin, } \\
\text { Osmaniye, Antakya, } \\
\text { Urfa, Bitlis, Van }\end{array}$ & $\begin{array}{l}\text { Assing (2007), } \\
\text { Assing (present paper), } \\
\text { SCHEERPELTZ (1958), } \\
\text { SMETANA (2004) } \\
\end{array}$ \\
\hline A. (Baryodma) milleri KraATZ, 1862 & $?$ & $\begin{array}{l}\text { Deyrolle (1873), } \\
\text { Smetana (2004) }\end{array}$ \\
\hline A. (Ceranota) bituberculata BeRNHAUER, 1900 & $\begin{array}{l}\text { Isparta/Afyon? (Sultan } \\
\text { Dağları), Bolu }\end{array}$ & $\begin{array}{l}\text { Assing (present paper), } \\
\text { BERNHAUER (1901), } \\
\text { BERNHAUER \& SCHEERPELTZ (1926), } \\
\text { FAGEL (1968), } \\
\text { SMETANA (2004) }\end{array}$ \\
\hline A. (Ceranota) bodemeyeri Bernhauer, 1900 & $\begin{array}{l}\text { Kocaeli/Sakaria (“Goek } \\
\text { Dagh”), Bolu }\end{array}$ & $\begin{array}{l}\text { Assing (present paper), } \\
\text { BERNHAUER (1900), } \\
\text { BERNHAUER (1901), } \\
\text { BERNHAUER \& SCHEERPELTZ (1926), } \\
\text { SMETANA (2004) }\end{array}$ \\
\hline A. (Ceranota) erythroptera GravenHoRst, 1806 & Aydın, Muğla, Kars & $\begin{array}{l}\text { Assing (present paper), } \\
\text { GANGLBAUER (1895), } \\
\text { Horion (1967), } \\
\text { SMETANa (2004) }\end{array}$ \\
\hline A. (Ceranota) lurida Mотschulsку, 1860 & Bolu & FAGEL (1968), SMETANA (2004) \\
\hline A. (Ceranota) ocaleoides (Bernhauer, 1902) & $?$ & \begin{tabular}{|l} 
Assing (2002), \\
BERNHAUER (1902), \\
SMETANA (2004) \\
\end{tabular} \\
\hline A. (Ceranota) plicata LOKAY, 1907 & Adana & $\begin{array}{l}\text { BERNHAUER \& SCHEERPELTZ (1926), } \\
\text { LOKAY (1907), } \\
\text { SMETANA (2004) } \\
\end{array}$ \\
\hline A. (Ceranota) subtumida (Носннитн, 1849) & $\begin{array}{l}\text { Izmir, Zonguldak, } \\
\text { Kastamonu, Sinop, Bitlis }\end{array}$ & $\begin{array}{l}\text { Assing (2004), } \\
\text { Assing (2006b), } \\
\text { Assing (present paper), } \\
\text { FAGEL (1968), } \\
\text { SMETANA (2004) } \\
\end{array}$ \\
\hline A. (Coprochara) bilineata Gyllenhal, 1810 & Gümüşhane, Artvin & \begin{tabular}{|l} 
Assing (present paper), \\
HoRion (1967), \\
SCHEERPELTZ (1960), \\
SMETANA (2004) \\
\end{tabular} \\
\hline A. (Coprochara) bipustulata (Linnaeus, 1760) & $\begin{array}{l}\text { Istanbul, Kocaeli, Izmir, } \\
\text { Ordu, Gümüşhane, Rize, } \\
\text { Muğla, Antalya, "Cilicia“, } \\
\text { Niğde, Konya, Antakya, } \\
\text { Malatya, Van } \\
\end{array}$ & $\begin{array}{l}\text { Assing (present paper), } \\
\text { Maus (1998), } \\
\text { Peyron (1858), } \\
\text { SCHEERPELTZ (1958), } \\
\text { SMETANA (2004) } \\
\end{array}$ \\
\hline A. (Coprochara) verna $\mathrm{S}_{\mathrm{AY}}, 1833$ & $\begin{array}{l}\text { Erzincan, central Anatolia } \\
\text { (Tuz Gölü), Erzurum, } \\
\text { Kahramanmaraş, } \\
\text { Gaziantep }\end{array}$ & $\begin{array}{l}\text { Assing (present paper), } \\
\text { MAus (1998), } \\
\text { SMETANA (2004) }\end{array}$ \\
\hline A. (Dyschara) inconspicua AuBÉ, 1850 & \begin{tabular}{|l|} 
Muğla, Antalya, \\
Ankara, Osmaniye, \\
Kahramanmaraş, Mardin \\
\end{tabular} & \begin{tabular}{|l} 
Assing (2006b), \\
Assing (2007), \\
Assing (present paper) \\
\end{tabular} \\
\hline A. (Euryodma) brevipennis Gravenhorst, 1806 & Mersin? & $\begin{array}{l}\text { Peyron (1858), } \\
\text { Smetana (2004) }\end{array}$ \\
\hline A. (Heterochara) bellonata KRÁsA, 1922 & Kahramanmaraş & Assing (2006b) \\
\hline
\end{tabular}




\begin{tabular}{|c|c|c|}
\hline Taxon & Turkish provinces & References \\
\hline A. (Heterochara) clavicornis REDTENBACHER, 1849 & Antakya, Kahramanmaraş & Assing (present paper) \\
\hline A. (Heterochara) spissicornis ERICHSON, 1839 & Erzurum, Konya, Mersin & $\begin{array}{l}\text { Assing (present paper), } \\
\text { SMETANA (2004) }\end{array}$ \\
\hline A. (Rheochara) leptocera Eppelsheim, 1889 & $?$ & $\begin{array}{l}\text { EPPELSHEIM (1889), } \\
\text { BERNHAUER (1901), } \\
\text { BERNHAUER \& SCHEERPELTZ (1926), } \\
\text { SCHEERPELTZ (1969a), } \\
\text { SMETANA (2004) }\end{array}$ \\
\hline A. (Rheochara) spadicea (ERICHSON, 1837) & Muğla & $\begin{array}{l}\text { Assing (present paper), } \\
\text { SCHEERPELTz (1969a), } \\
\text { SMETANA (2004) }\end{array}$ \\
\hline A. (Xenochara) cuniculorum KrAATZ, 1858 & Konya & AssiNG (present paper) \\
\hline A. (Xenochara) discipennis Mulsant \& ReY, 1853 & Istanbul, Mersin & Assing (present paper) \\
\hline A. (Xenochara) fumata Gravenhorst, 1802 & ? & $\begin{array}{l}\text { BERNHAUER (1901), } \\
\text { SMETANA }(2004)\end{array}$ \\
\hline A. (Xenochara) funebris Wollaston, 1864 & Konya & Assing (present paper) \\
\hline A. (Xenochara) haematoptera KRAATZ, 1858 & $\begin{array}{l}\text { Istanbul, Amasya, Sinop, } \\
\text { Trabzon, Niğde, Tunceli, } \\
\text { Osmaniye, Antakya, } \\
\text { Kahramanmaraş, Siirt, } \\
\text { Bitlis, Van }\end{array}$ & $\begin{array}{l}\text { Assing (present paper), } \\
\text { Horion (1967), } \\
\text { SMETANA (2004) }\end{array}$ \\
\hline A. (Xenochara) honesta LiкovsкÝ, 1973 & Gümüşhane, Rize, Artvin & Assing (2007) \\
\hline A. (Xenochara) ignipennis FAUVEL, 1900 & Adana, Bitlis & $\begin{array}{l}\text { Assing (2007), } \\
\text { Assing (present paper) }\end{array}$ \\
\hline A. (Xenochara) laevigata Gyllenhal, 1810 & $\begin{array}{l}\text { Gümüşhane, Mersin?, } \\
\text { Urfa, Bitlis, Van }\end{array}$ & $\begin{array}{l}\text { Assing (present paper), } \\
\text { PEYRon (1858), } \\
\text { SMETANA (2004) }\end{array}$ \\
\hline A. (Xenochara) lanuginosa Gravenhorst, 1802 & Bolu, Osmaniye & $\begin{array}{l}\text { Assing (present paper), } \\
\text { Horion (1967), } \\
\text { SMETANA (2004) }\end{array}$ \\
\hline A. (Xenochara) lygaea KRAATZ, 1862 & Artvin, Tunceli, Bitlis & Assing (present paper) \\
\hline A. (Xenochara) maculata Brisout, 1863 & Gümüşhane, Erzurum & Assing (2007) \\
\hline A. (Xenochara) maculipennis BAUdI, 1857 & $\begin{array}{l}\text { Konya, Kahramanmaraş, } \\
\text { Urfa, Hakkâri }\end{array}$ & $\begin{array}{l}\text { Assing (2007), } \\
\text { Assing (present paper) }\end{array}$ \\
\hline A. (Xenochara) moerens GyllenHAL, 1827 & $?$ & SMETANA (2004) \\
\hline $\begin{array}{l}\text { A. (Xenochara) moesta Gravenhorst, } 1802 \\
=\text { ebneri SCHEerpeltz, } 1929, \text { syn. } \mathrm{n} .\end{array}$ & $\begin{array}{l}\text { Erzurum, Tunceli, Bitlis, } \\
\text { Van }\end{array}$ & $\begin{array}{l}\text { Assing (2007), } \\
\text { Assing (present paper), } \\
\text { PeYron (1858), } \\
\text { SMETANA (2004), } \\
\text { SCHEERPELTZ (1934) } \\
\end{array}$ \\
\hline A. (Xenochara) puberula KLUG, 1832 & Osmaniye & $\begin{array}{l}\text { Assing (present paper), } \\
\text { SMETANA (2004) }\end{array}$ \\
\hline A. (Xenochara) sparsa HeEr, 1839 & Istanbul, Rize & $\begin{array}{l}\text { Assing (2007), } \\
\text { Assing (present paper) }\end{array}$ \\
\hline A. (Xenochara) stichai LıкоvsкÝ, 1965 & Giresun & Assing (2007) \\
\hline
\end{tabular}




\begin{tabular}{|l|l|l|}
\hline Taxon & Turkish provinces & References \\
\hline A. (Xenochara) tristis Gravenhorst, 1806 & Erzurum, Artvin, & Assing (present paper), \\
& Konya, Mersin, & DeYrolle (1873), \\
& Osmaniye, Antakya, & Horion (1967), \\
& Kahramanmaraş, & SmETANA (2004) \\
& Gaziantep, Urfa, Mardin, & \\
& Malatya, Bitlis & \\
\hline A. (?) caloderoides sp. n. & Mersin & Assing (present paper) \\
\hline
\end{tabular}

\section{Acknowledgements}

My thanks are due to the colleagues indicated in the material section, as well as to Benedikt Feldmann (Münster) for proof-reading the manuscript.

\section{References}

Assing, V. 1994: Zur Kurzflügelkäferfauna xerothermer Flächen im südlichen Niedersachsen (Coleoptera: Staphylinidae). - Göttinger naturkundliche Schriften 3: 7-31.

Assing, V. 2000: A revision of the species of Euryalea Mulsant \& Rey and Pseudocalea Luze (Coleoptera, Staphylinidae, Aleocharinae). Supplement I. - Entomologische Blätter 96: 3-8.

Assing, V. 2002: A taxonomic and phylogenetic revision of Amarochara Thomson. I. The species of the Holarctic region (Coleoptera: Staphylinidae, Aleocharinae, Oxypodini). - Beiträge zur Entomologie, Keltern 52: 111-204.

Assing, V. 2004: New species and records of Staphylinidae from Turkey II (Insecta: Coleoptera: Staphylinidae) - Beiträge zur Entomologie, Keltern 54: 53-73.

Assing, V. 2006a: New species and records of Staphylinidae from Greece, with two new synonymies (Insecta: Coleoptera). - Linzer biologische Beiträge 38: 333-379.

Assing, V. 2006b: New species and records of Staphylinidae from Turkey IV, with six new synonymies (Coleoptera: Staphylinidae). - Koleopterologische Rundschau 76: 223-276.

Assing, V. 2007: New species and additional records of Staphylinidae from Turkey V (Coleoptera). Stuttgarter Beiträge zur Naturkunde, Serie A (Biologie) 700: 1-64.

Assing, V. \& SchüLKe, M. in press: Supplemente zur mitteleuropäischen Staphylinidenfauna (Coleoptera, Staphylinidae). III. - Entomologische Blätter (2007).

Bernhauer, M. 1900: Neue Staphyliniden (Coleoptera) aus dem Kaukasus und den angrenzenden Ländern. - Wiener Entomologische Zeitung 19: 46-55.

Bernhauer, M. 1901: Die Staphyliniden der paläarktischen Fauna. - Verhandlungen der kaiserlich-königlichen zoologisch-botanischen Gesellschaft in Wien 51: 430-506.

Bernhauer, M. 1902: Die Staphyliniden der paläarktischen Fauna. I. Tribus Aleocharini (II. Theil). Verhandlungen der kaiserlich-königlichen zoologisch-botanischen Gesellschaft in Wien 52: 87-284.

Bernhauer, M. 1914: Beiträge zur Kenntnis der paläarktischen Staphyliniden-Fauna. - Münchener Koleopterologische Zeitschrift 4: 33-45.

Bernhauer, M. \& Scheerpeltz, O. 1926: Staphylinidae VI. - In: Junk, W. \& Schenkling, S. (eds.): Coleopterorum Catalogus, pars 82, Berlin: 499-988.

Deyrolle, T. 1873: Enumération des Staphylinides recueillis en Asie Mineure. - Revue et Magasin de Zoologie 1: 410-414.

Eppelsheim, E. 1889: Neue Staphylinen Europa's und der angrenzenden Länder. - Deutsche Entomologische Zeitschrift 33: 161-183. 
FAGEL, G. 1968: Contribution a la connaissance des Staphylinidae. CVI. Remarques diverses sur des espèces de la région paléarctique occidentale. - Bulletin et Annales de la Société Royale d'Entomologie de Belgique 104: 189-204.

Ganglbauer, L. 1895: Die Käfer von Mitteleuropa. 2. Band. Familienreihe Staphylinoidea. 1. Theil: Staphylinidae, Pselaphidae. - Wien: 880 pp.

Horion, A. 1967: Faunistik der mitteleuropäischen Käfer. Bd. XI: Staphylinidae, 3. Teil: Habrocerinae bis Aleocharinae (ohne Subtribus Athetae). - Überlingen-Bodensee: 419 pp.

Likovksкx́, Z. 1973: Bemerkungen über die Gattung Aleochara Gravenhorst (Coleoptera, Staphylinidae). - Annotationes Zoologicae et Botanicae 71: 1-8.

LokaY, E. 1907: Nová Aleochara z. podrodu Ceranota. STEPH. - Časopis České Společnosti Entomologické 4: 78-81.

Maus, Ch. 1998: Taxonomical contributions to the subgenus Coprochara Mulsant \& Rey, 1874 of the genus Aleochara Gravenhorst, 1802 (Coleoptera: Staphylinidae). - Koleopterologische Rundschau 68: 81-100.

Peyron, E. 1858: Catalogue des coléoptères des environs de Tarsous (Caramanie), avec la description des espèces nouvelles. - Annales de la Société Entomologique de France 6: 353-434.

Scheerpeltz, O. 1929: Staphyliniden (Coleoptera) aus Palästina und Syrien. Zoologische Studienreise von R. Ebner 1928 mit Unterstützung der Akademie der Wissenschaften in Wien. - Sitzungsberichte der Akademie der Wissenschaften in Wien Mathematisch-naturwissenschaftliche Klasse. Abteilung I 138: 211-250.

Scheerpeltz, O. 1934: Zwei neue Arten der Gattung Aleochara Gravenhorst (Coleoptera, Staphylinidae), die aus den Puppen von Lyperosia als Parasiten gezogen wurden. - Revue Suisse de Zoologie 41: 131-147.

Scheerpeltz, O. 1958: Wissenschaftliche Ergebnisse der von Herrn Dr. K. Lindberg, Lund, im Jahre 1956 nach der Türkei und Armenien unternommenen Reise. Coleoptera-Staphylinidae. - Entomologisk Tidskrift (Supplementum) 78 (1957): 3-37.

Scheerpeltz, O. 1960: Die von Prof. Dr. Håkan Lindberg während seiner 1959 nach Portugal unternommenen Studienreise aufgesammelten Staphyliniden (Coleoptera). - Notulae Entomologicae 40: 132-139.

Scheerpeltz, O. 1969a: Eine neue Art der Gattung Rheochara Mulsant-Rey, nebst einer Bestimmungstabelle der bis heute aus dieser Gattung bekannt gewordenen Arten (Coleoptera, Staphylinidae). - Koleopterologische Rundschau 46/47 (1968/1969): 119-126.

Scheerpeltz, O. 1969b: Nachtrag zu meiner Arbeit über die Arten der Gattung Rheochara Mulsant-Rey (Koleopterologische Rundschau, XLVI, 1968). - Annalen des Naturistorischen Museums in Wien 73: 377-378.

Smetana, A. 2004: Staphylinidae, subfamilies Omaliinae-Dasycerinae, Phloeocharinae-Apaticinae, Piestinae-Staphylininae, pp. 237-272, 329-495, 505-698. - In: LöBL, I. \& SMETANA, A. (editors): Catalogue of Palaearctic Coleoptera. II. Hydrophiloidea - Histeroidea - Staphylinoidea. Stenstrup: Apollo Books, 942 pp.

Author's address:

Dr. Volker Assing

Gabelsbergerstr. 2

D - 30163 Hannover

Germany

e-mail: vassing.hann@t-online.de

\section{Subject Editor:}

Prof. Dr. B. Klausnitzer 